This is the final peer-reviewed accepted manuscript of:

Gusmeo Thomas; William Cavazza; Victor Alania; Onise Enukidze; Massimiliano Zattin; Sveva Corrado:

Structural inversion of back-arc basins-The Neogene Adjara-Trialeti fold-and-thrust belt (SW Georgia) as a far-field effect of the Arabia-Eurasia collision. TECTONOPHYSICS 803. 0040-1951

DOI: $10.1016 / j . t e c t o .2020 .228702$

The final published version is available online at:

http://dx.doi.org/10.1016/j.tecto.2020.228702

Rights / License:

The terms and conditions for the reuse of this version of the manuscript are specified in the publishing policy. For all terms of use and more information see the publisher's website.

This item was downloaded from IRIS Università di Bologna (https://cris.unibo.it/)

When citing, please refer to the published version. 


\title{
Structural inversion of back-arc basins-The Neogene Adjara-Trialeti fold-and-thrust belt (SW Georgia) as a far-field effect of the Arabia-Eurasia collision
}

\author{
Thomas Gusmeo ${ }^{\mathrm{a},{ }^{\star}}$, William Cavazza ${ }^{a}$, Victor M. Alania ${ }^{\mathrm{b}}$, Onise V. Enukidze ${ }^{\mathrm{b}}$, \\ Massimiliano Zattin ${ }^{\mathrm{c}}$, Sveva Corrado ${ }^{\mathrm{d}}$ \\ a Department of Biological, Geological and Environmental Sciences, Univ. of Bologna, Italy \\ ${ }^{b}$ Institute of Geophysics, I. Javakhishvili State University, Tbilisi, Georgia \\ 'Department of Geosciences, Univ. of Padova, Italy \\ d Department of Sciences, Roma Tre University, Rome, Italy
}

A R T I C L E I N F O

Keywords:

Fission-track analysis

(U-Th)/He analysis

Lesser Caucasus

Rift inversion

Far-field tectonics

Arabia-Eurasia collision

\begin{abstract}
A B S T R A C T
The $350 \mathrm{~km}$-long Adjara-Trialeti fold-and-thrust belt of southwestern Georgia is the result of the structura inversion of a continental back-arc basin developed in the Paleogene on the upper (Eurasian) plate of the northward subducting northern branch of the Neotethys. Low-temperature thermochronological data [fissiontrack and (U-Th)/He analyses on apatite] from sedimentary and plutonic rocks provide robust constraints on the tectonic evolution of the Adjara-Trialeti orogenic belt. Fission-track central ages range from the Middle Eocene to the Middle Miocene (46-15 Ma); helium ages are clustered in the Late Miocene-Pliocene (10-3 Ma). Time-temperature paths obtained integrating thermochronologic, stratigraphic, and radiometric data show that the volcanosedimentary basin fill of the Adjara-Trialeti back-arc basin underwent progressive burial heating prior to final cooling/exhumation in the late Middle Miocene-Pliocene. These new data show that the AdjaraTrialeti back-arc basin was inverted and developed as a fold-and-thrust belt starting at 14-10 Ma, in tune with widespread Middle-to-Late Miocene shortening and exhumation across wide areas of the Middle East, from the eastern Pontides of NE Turkey to the Lesser Caucasus in northern Armenia and NW Azerbaijan, and the Talysh and Alborz ranges in northern Iran. Such a supraregional tectonism is interpreted as a far-field effect of the Arabia-Eurasia collision along the Bitlis suture ca. $400 \mathrm{~km}$ to the south of the study area.
\end{abstract}

\section{Introduction}

Back-arc rifts develop in response to a decrease in plates convergence rates, inducing steepening and rollback of the subducting lower plate lithospheric slab and concurrent upper plate extension (e.g. Doglioni et al., 2007; Miall, 2013; Uyeda and McCabe, 1983). Back-arc rifting along active continental margins can lead to crustal separation and the opening of deep marine basins floored by either oceanic or highly extended continental lithosphere (e.g. South China Sea, Sea of Japan, Tyrrhenian Sea). However, as plates convergence rates are variable in time and space, back-arc basins are usually transitory. Following an increase in convergence rates and the ensuing shallowing of the sub-ducting lower plate, back-arc extensional basins are liable to structural inversion by compressional stresses (Cloetingh et al., 1989; Hall et al.,
2011; Jolivet et al., 1989; Letouzey et al., 1990; Munteanu et al., 2011; Nikishin et al., 2001; Uyeda and McCabe, 1983; Ziegler, 1990).

Back-arc basins can be also deformed and inverted during continent- continent collisions, when horizontal compressional stress can travel far from suture zones inducing the formation/reactivation of an array of compressional/transpressional structures, such as lithospheric folding, basement upthrusting and overall basin inversion both in the foreland and the hinterland (Cloetingh et al., 2005; Cowgill et al., 2016; Ziegler et al., 2002, 1998, 1995; Zoback, 1992). Collisionrelated stresses can bypass the orogenic wedge and focus along rheological discontinuities at distances in excess of $10^{3} \mathrm{~km}$ from the collisional front (Ziegler et al., 2002). Basin inversion is favoured by the existence of preexisting structural weaknesses as well as the lower density and rheological strength of the sedimentary fill compared to the surrounding crust. In

\footnotetext{
* Corresponding author at: Piazza di Porta San Donato 1, 40126 Bologna, Italy.

E-mail address: thomas.gusmeo2@unibo.it (T. Gusmeo).
} 
addition, young sedimentary basins can localize shortening more efficiently because the extensional thermal signature not yet dissipated makes them weaker.

In this paper, we present the first low-temperature thermochronological dataset on the Adjara-Trialeti back-arc rift basin of southwestern Georgia, which developed along the Eurasian continental margin during the latest stage of northward subduction of the Neotethys (Adamia et al., 2010; Yllmaz et al., 2014, 2000). Our data indicate that the Paleogene sedimentary fill of the AdjaraTrialeti basin has been structurally inverted and developed as a fold-and-thrust belt starting from the late Middle Miocene. Coeval compressional deformation took place over a wide area comprising from west to east- the eastern Pontides of northeastern Turkey, portions of the Lesser Caucasus in northern Armenia and northwestern Azerbaijan, and the Talysh and Alborz ranges of northern Iran (Albino et al., 2014; Ballato et al., 2013; Cavazza et al., 2019, 2015; Guest et al., 2006; Madanipour et al., 2017). We interpret this overall state of compression and selective reactivation of older structures as a far-field effect of the coeval Arabia-Eurasia continental collision along the Bitlis-Zagros suture, located more than 400 $\mathrm{km}$ to the south of the Adjara-Trialeti fold-and-thrust belt.

The Adjara-Trialeti fold-and-thrust belt (ATFTB) of southwestern Georgia is an E-W-trending orogen spanning some $350 \mathrm{~km}$ from the Black Sea coast to east of Tbilisi (Fig. 1). The maximum surficial width of the belt is about $50 \mathrm{~km}$ close to the Black Sea and decreases progressively to the east. In eastern Georgia, the ATFTB plunges to the east and it is covered by highly deformed oligocene-to-Miocene sedimentary rocks of the Kura basin fill. To the west it continues offshore in the eastern Black Sea, where it is known as Gurian fold belt (e.g. Tari and Simmons, 2018).

Geodetic data indicate that the ATFTB is tectonically active and accommodates $3-6 \mathrm{~mm} / \mathrm{yr}$ of the present convergence rate between the eastern Anatolian Plateau and Eurasia (Reilinger et al., 2006; Sokhadze et al., 2018) (Fig. 2). The major earthquakes within the fold-and-thrust belt are characterized by transpressive focal mechanisms (Sokhadze et al., 2018; Tsereteli et al., 2016). Seismicity is higher in the Rioni-

\section{Geological and geophysical background}

Kartli-Kura foreland basin to the north (Adamia et al., 2017a; Tibaldi et al., 2017) where fault-plane solution data indicate ongoing northsouth-oriented compression and convergence rates can reach $12 \mathrm{~mm} /$ yr (Forte et al., 2014, 2013; Karakhanyan et al., 2013; Reilinger et al., 2006). Crustal thickness along the ATFTB ranges between 35 and 45 $\mathrm{km}$, whereas the lithospheric thickness is $130-140 \mathrm{~km}$ (Adamia et al., 2017b; Motavalli-Anbaran et al., 2016).

The ATFTB is bordered to the north by frontal thrusts and associated fault-propagation folds (Adamia et al., 2017b, 1992; Alania et al., 2018; Banks et al., 1997; Nemčok et al., 2013) (Fig. 2). Shortening along the northern frontal structures is estimated at ca. $15 \mathrm{~km}$ (Bazhenov and Burtman, 2002); northward propagation of such frontal structures has induced deformation of the southern margins of the Rioni and Kartli foreland basins (Alania et al., 2017; Banks et al., 1997; Nemčok et al., 2013). The Dzirula massif, a polymetamorphic salient in central Georgia (Figs. 1, 2), was already at the surface during the development of the ATFTB (Vincent et al., 2011) and acted as a relatively rigid indenter during the northward propagation of the belt, as shown by the curvature of the frontal thrusts close to the massif (Fig. 2). Surface relationships between the ATFTB and the Khrami Massif to the south are hidden by a thick cover of latest Miocene-toQuaternary subaerial lava flows and pyroclastic deposits (Adamia et al., 2017b, 2011, 2008, 1981; Okrosts-varidze et al., 2018b). The boundary and structural relationship between the Adjara-Trialeti and the Eastern Pontides (NE Anatolia) orogenic belts are unclear due to a thick vegetation cover.

Fig. 3 shows the overall stratigraphy of the eastern sector of the ATFTB. To the west precise correlation is hampered by limited exposure. The age of the pre-rift sedimentary succession ranges from the late Early Cretaceous to the Early Eocene. The Aptian-Cenomanian volcanics and volcaniclastics of the ATFTB have been interpreted as connected to either (i) the Eastern Pontides-Lesser Caucasus subduction-related magmatic arc, located immediately to the south (Adamia et al., 1992, 1981; Yllmaz et al., 2014) or (ii) to the opening of the Eastern Black Sea (Nikishin et al., 2015a, 2015b). While there is ample evidence that the western Black Sea opened in late Early Cretaceous times (e.g. Finetti et al., 1988; Gorür, 1988; Munteanu et al., 2011; Nikishin et al., 2011, 2001), arguably as an extensional backarc basin related to the north-ward subduction of the Neotethys (e.g. Letouzey et al., 1977; Nikishin

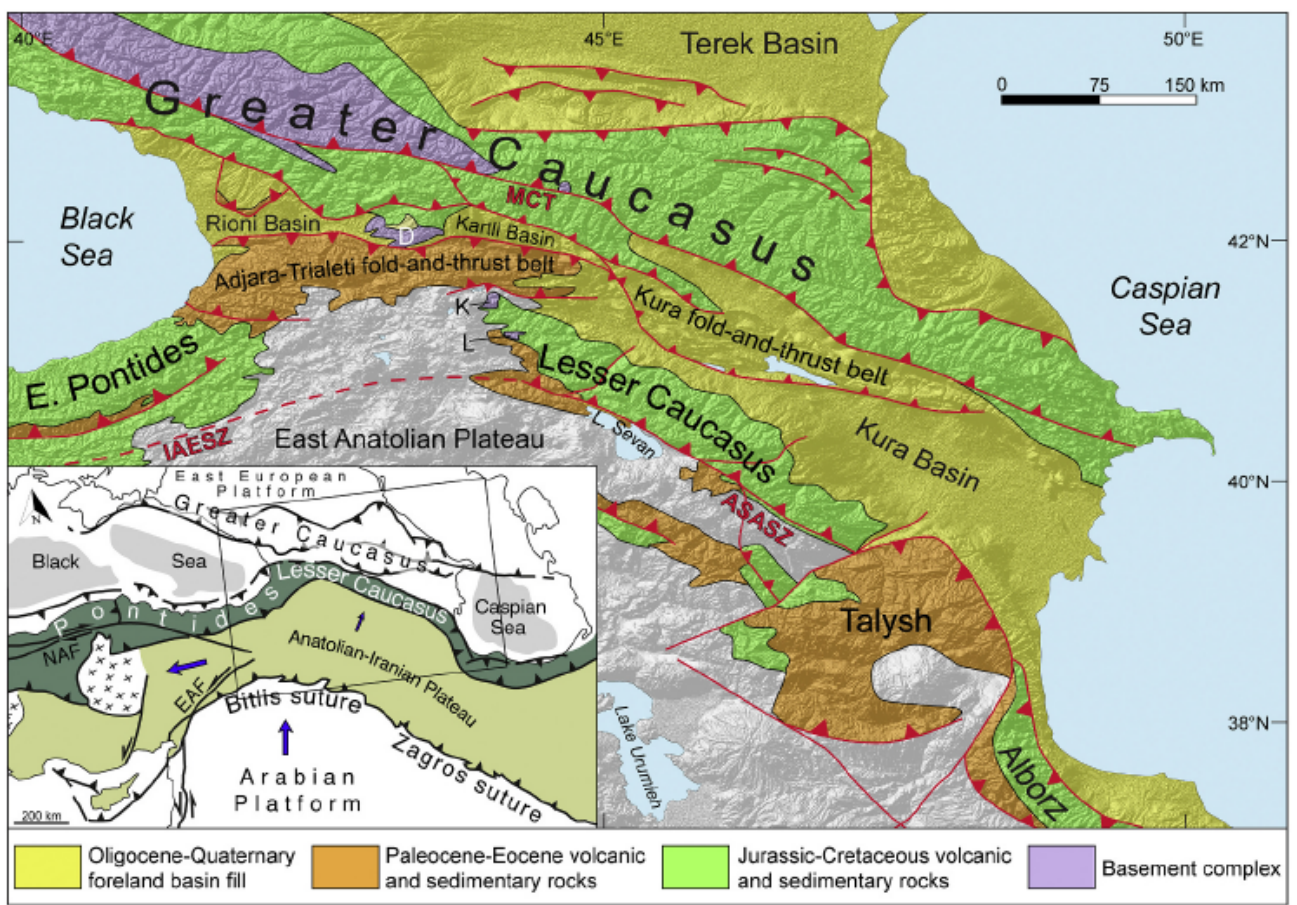

Fig. 1. Main tectonic units and structures of the Eastern Anatolia-Caucasian region superimposed on an ASTER GDEM shaded relief map (source: USGS). ASASZ = Amasia- Sevan-Akera suture zone; D = Dzirula Massif; IAESZ = Izmir-AnkaraErzinçan su-ture zone; $\mathrm{K}=$ Khrami Massif; $\mathrm{L}$ = Loki Massif; MCT = Main Caucasian Thrust. Red lines with triangles indicate thrusts; red lines are normal, strike-slip or unknown kine-matics faults. Inset: Tectonic sketch map of the Arabia-Eurasia collision zone modified after Cavazza et al. (2019) and Sosson et al. (2010). EAF = Eastern Anatolian Fault; NAF = Northern Anatolian Fault. (For interpre-tation of the references to colour in this figure legend, the reader is referred to the web version of this article.) 


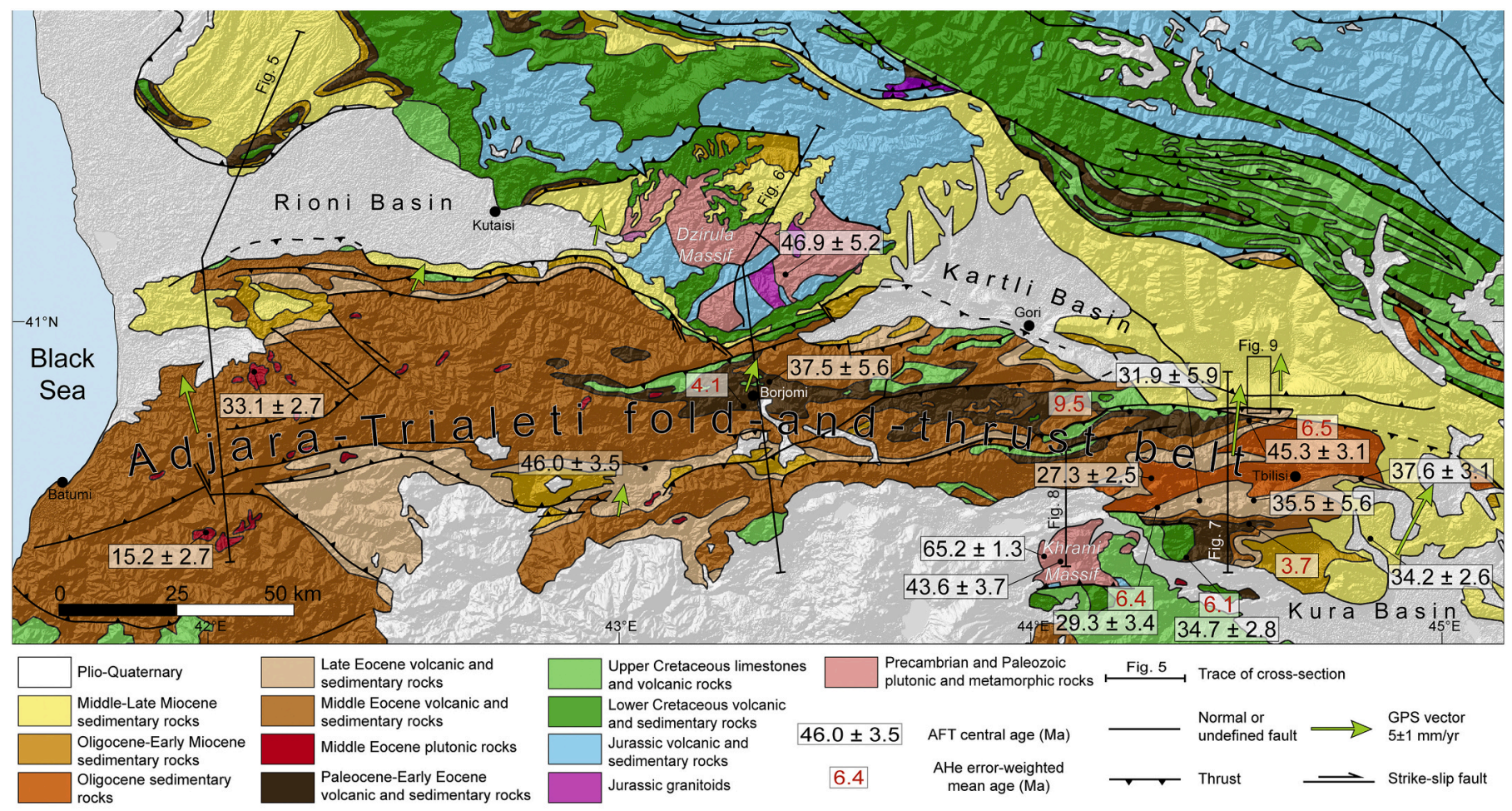

Fig. 2. Geological sketch map of the Adjara-Trialeti fold-and-thrust belt and the surrounding regions (modified from Adamia, 2004; USSR Geological Survey, 1957a, 1957b, 1956a, 1956b, 1956c). For analytical details of apatite fission-track central ages and (U-Th)/He mean ages and exact samples locations, see Tables 1 and 2. Traces of geological cross-sections of Figs. 5, 6, 7 and 8 and location of Fig. 9 are also shown.

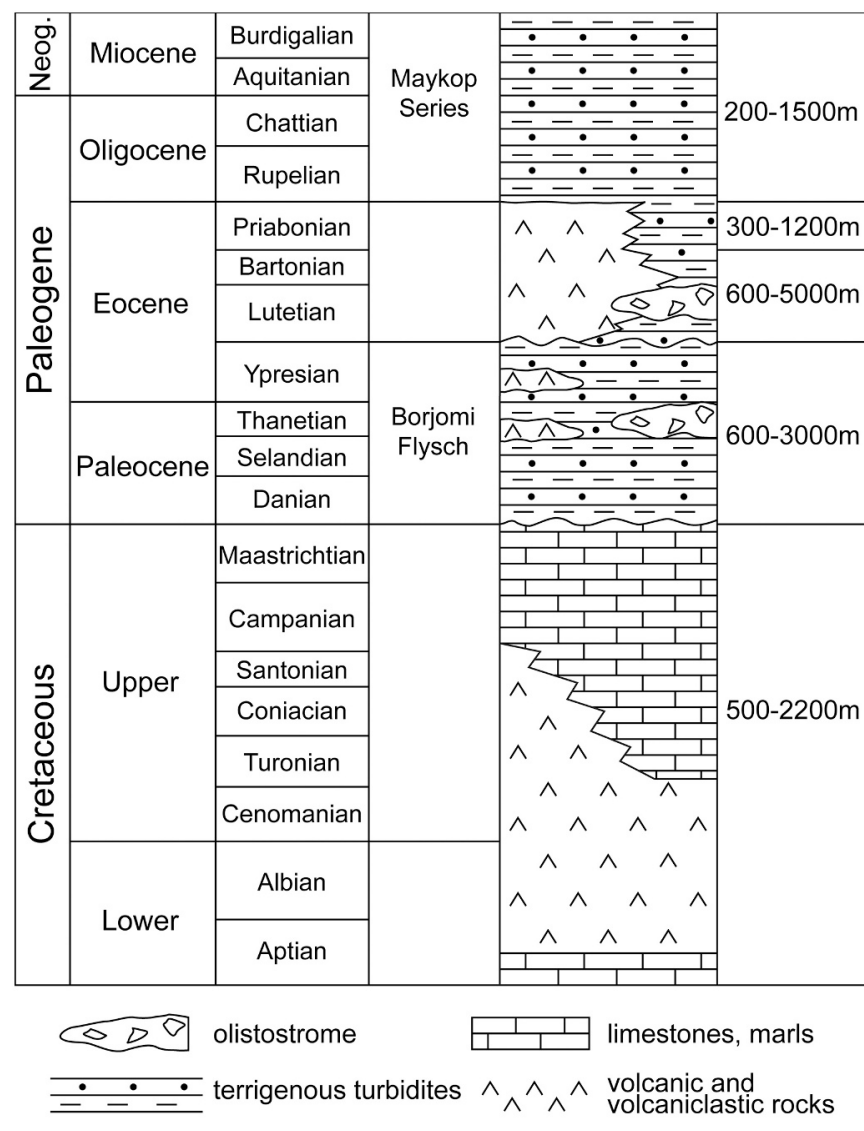

Fig. 3. Schematic chronostratigraphy of the Adjara-Trialeti region. Sources: Adamia et al., 2017b, 2011; Gamkrelidze et al., 2018; Y1lmaz et al., 2014, 2000 . et al., 2011; Okay et al., 1994), the timing of opening of the eastern Black Sea has been variously interpreted as coeval with the western Black Sea (e.g. Nikishin et al., 2015a, 2015b, 2003; Okay et al., 1994; Zonenshain and Le Pichon, 1986), as late Campanian-Danian (Vincent et al., 2016), Paleocene-Early Eocene (Robinson et al., 1996, 1995a, 1995b; Shillington et al., 2008; Spadini et al., 1996) or as Eocene (Kazmin et al., 2000). As a whole, the formation of the Black Sea basins has been explained in terms of geodynamic models derived from the study of modern back-arc basins, where extension is driven by slab roll- back. For example, Stephenson and Schellart (2010) interpreted the Black Sea as an asymmetric back-arc basin bordering a subduction slab undergoing asymmetric anticlockwise slab roll-back, a model compat-ible with an earlier onset of extensional structures in the western compared to the eastern sub-basin.

Adjara-Trialeti subsidence increased rapidly in the Paleocene, with the development of an east-west-trending elongate basin and the deposition of a thick succession of terrigenous turbidites (PaleoceneYpresian Borjomi Flysch; Fig. 3) (Adamia et al., 2011; Banks et al., 1997; Y1lmaz et al., 2014, 2000). During this period, the AdjaraTrialeti region was located in the northern foreland of the ErzinçanSevan-Akera oro-gen and was experiencing flexural subsidence. The flexural interpreta-tion of the Borjomi subsidence is supported by the progressive eastward thickening of the Borjomi Flysch (Gamkrelidze, 1949; Y1lmaz et al., 2000), as the oblique collision between the Anatolide-Tauride terrane and the southern Eurasian margin (Barrier et al., 2018) induced a gradient of increasing subsidence from west to east (Fig. 4). Back-arc rifting occurred in the Middle Eocene (Fig. 4), as shown by a thick succession of volcaniclastic turbidites interbedded with submarine vol-canic rocks (Adamia et al., 2011, 1981, 1977; Okrostsvaridze et al., 2018a). The Middle Eocene section thickens dramatically toward the Black Sea coast, where it reaches ca. $5000 \mathrm{~m}$ (Adamia et al., 2011; Gamkrelidze et al., 2019; Okrostsvaridze et al., 2018a) and volcanic/ hypabyssal rocks are most abundant (Okrostsvaridze et al., 2018b). In the Late Eocene, mostly epiclastic turbidites were being deposited in the 


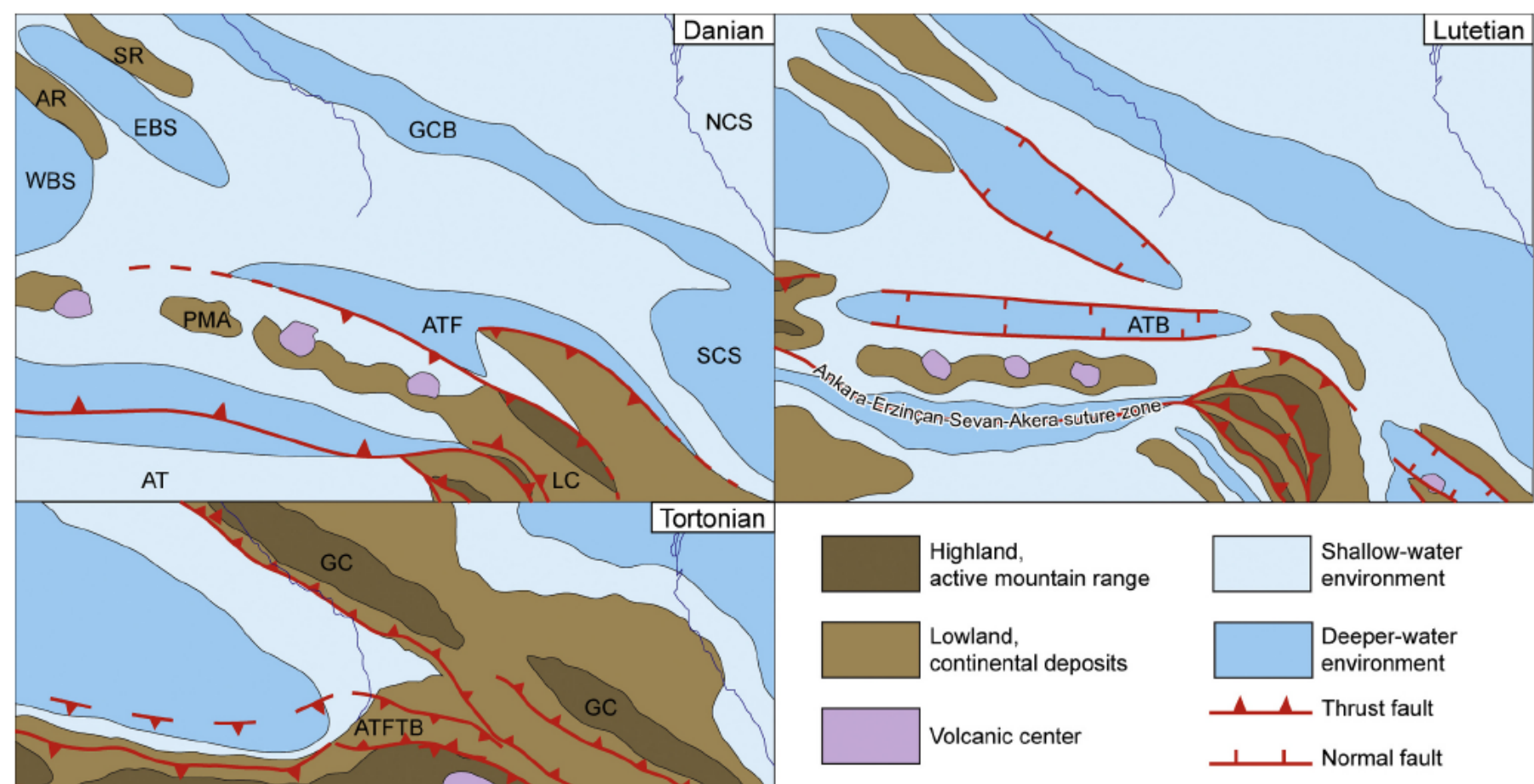

AR=Andrusov Ridge; $A T=$ Anatolide-Tauride Block; ATB= Adjara-Trialeti basin; ATF= Adjara-Trialeti foreland basin; ATFTB= Adjara-Trialeti fold-and-thrust belt, $\mathrm{EAP}=$ East Anatolian Plateau; EBS= Eastern Black Sea basin;

$\mathrm{GC}=$ Greater Caucasus; GCB= Greater Caucasus basin; LC= Lesser Caucasus; NCS= North Caspian Sea basin; PMA = Pontide magmatic arc; $S C S=$ South Caspian Sea basin; SR= Shatsky Ridge; WBS= Western Black Sea basin.

Fig. 4. Paleogeographic sketch maps of the Black Sea-Caucasian region (modified from Barrier et al., 2018). During the Danian (Early Paleocene), the AdjaraTrialeti region was affected by flexural subsidence related to the progressive development of the Ankara-Erzinçan suture to the south. In the Lutetian (Middle Eocene), the rollback of the Neotethyan slab induced upper-plate extension and the development of the Eastern Pontides intra-arc/back-arc extensional basin, partly superposed on the Adjara-Trialeti basin which was then experiencing peak subsidence. In the Tortonian (Late Miocene), following complete Arabia-Eurasia collision, the Adjara- Trialeti-Eastern Pontides rift system was inverted.

eastern sector of the ATFTB, whereas volcaniclastic turbidites interbedded with lava sheets and pyroclastic rocks were predominant in the central and western sectors (Adamia et al., 2017b, 2011; Gamkrelidze et al., 2018). Seismic data show that the ATFTB continues offshore in the Eastern Black Sea and suggest coeval extension in the Black Sea Pontide domain and in the Adjara-Trialeti basin (Banks et al., 1997; Robinson et al., 1995b, 1996, 1997; Shillington et al., 2008; Tari et al., 2018).

During Oligocene-Early Miocene (Maykopian) times the AdjaraTrialeti basin saw the deposition of terrigenous turbidites, locally interbedded with shales, marls and fine-grained sandstones indicating an anoxic/disoxic environment (Pupp et al., 2018; Sachsenhofer et al., 2018) (Fig. 4). The youngest deposits are Sarmatian (ca. 12-10 Ma) shallow-water siliciclastics and oolitic limestones (Adamia et al., 2017b, 2011; Gamkrelidze et al., 2019). Inversion of the AdjaraTrialeti back- arc basin has been generically indicated as OligoceneMiocene (Adamia et al., 2010, 1981, 1977; Banks et al., 1997; Sosson et al., 2016). The chronological definition of such a structural inversion and its interpre-tation in a wider geodynamic scenario is the objective of this study.

\section{Analytical methods}

\subsection{Apatite fission-track analysis and modelling}

Fission-track dating is a useful tool to unravel the cooling histories experienced by rocks in the upper crustal levels and to give a measure of their exhumation (for a review, see Donelick et al., 2005). Fission tracks are linear radiation damages within the crystal lattice, caused by the nuclear fission of radioactive isotope ${ }^{238} \mathrm{U}$, which can be etched and counted under an optical microscope. Concurrently, neutron irradiation is used to induce the decay of ${ }^{235} \mathrm{U}$, generating radiation damages on the surface of an external detector. Grain-by-grain determination of both spontaneous and induced fission-track densities yields a single-grain age representing the cooling of the grain below a closure temperature of $\sim 100^{\circ} \mathrm{C}$. Fission tracks in apatites have the same initial length of about $16 \mu \mathrm{m}$ (Donelick et al., 1999; Ketcham et al., 1999) but anneal at rates proportional to temperature, starting at about $60{ }^{\circ} \mathrm{C}$. Over geological time periods, partial annealing of fission tracks occurs at temperatures between about 60 and $120{ }^{\circ} \mathrm{C}$ (the Partial Annealing Zone or PAZ; Gleadow and Duddy, 1981). Because tracks shorten in relation to the degree and duration of heating, the measurement of fission-track lengths gives information about the thermal evolution in the PAZ temperature range. A quantitative evaluation of the thermal history can be carried out through modelling procedures, which find a range of cooling paths compatible with the fission-track length frequency distribution (Ket-cham, 2005). In this work, inverse modelling of track length data was performed using the HeFTy program (Ketcham, 2005), which generates the possible T-t paths by a Monte Carlo algorithm. Predicted AFT data were calculated according to the Ketcham et al. (2007) annealing model for fission tracks revealed by etching. Dpar values (i.e. the etch pit length) were used to define the annealing kinetics.

\subsection{Apatite $(U-T h) / H e$ analysis}

(U-Th)/He (AHe) dating is based upon the decay of radioactive 
isotopes ${ }^{238} \mathrm{U},{ }^{235} \mathrm{U}$, and ${ }^{232} \mathrm{Th}$ to give as products ${ }^{206} \mathrm{~Pb},{ }^{207} \mathrm{~Pb}$, and ${ }^{208} \mathrm{~Pb}$, respectively. ${ }^{4} \mathrm{He}$ nuclei ( $\alpha$ particles) are emitted at each step of this decay series and hence are the daughter nuclides for this dating system (Lisker et al., 2009; Reiners, 2005). In (U-Th)/He thermochronology, the closure temperature (Tc) is depending on a number of factors, such as crystal size, eU and radiation damage (Flowers et al., 2009; Gautheron et al., 2009). Moreover, production-diffusion model predicts that the effective $\mathrm{He}$ closure temperature of apatite will vary with cooling rate and effective $\mathrm{U}$ - and Th-concentration, and may differ from the commonly assumed temperature of $70{ }^{\circ} \mathrm{C}$ by up to $\pm 15{ }^{\circ} \mathrm{C}$ (e.g. Farley, 2002, 2000; Farley et al., 1996; Flowers et al., 2009; Shuster et al., 2006; Shuster and Farley, 2009; Wolf et al., 1998, 1996). It follows that AHe ages should be younger than AFT ages because of the lower closure temperature (for a review, see Peyton and Carrapa, 2013). The He Partial Retention Zone (PRZ) is the temperature interval where some $\mathrm{He}$ can be slowly lost through diffusion. The PRZ in apatite is usually assumed to be between $\sim 40$ and $70{ }^{\circ} \mathrm{C}$, but experimental data have demonstrated that this range can widen depending on the diffusion ki-netics of the grains (Flowers et al., 2015, 2009; Gautheron et al., 2009; Shuster and Farley, 2009). Another important issue in AHe thermo-chronometry is that $\alpha$ particles emitted during decay can travel for $20 \mu \mathrm{m}$ inside the crystal lattice of apatites: thus some $\mathrm{He}$ can be lost if emission occurs within that distance from the crystal edge, and ages should be corrected accordingly (Farley, 2002; Farley et al., 1996).

\subsection{Sampling strategy and sample preparation}

Twenty-one samples were collected from sedimentary rocks of the ATFTB, four samples were collected from intrusions in the central and western ATFTB, two samples were collected from the Dzirula Massif, and four samples from the Khrami Massif, for a total of thirty-one samples. Sedimentary rocks from the ATFTB are sandstones ranging in age from the Aptian-Albian to the Early Miocene. The intrusives are diorites and syenites of Eocene age. One sample from the Dzirula Massif is a Bajocian andesite, the other is a Late Paleozoic (Variscan) granitoid. Three samples from the Khrami Massif are Variscan granitoids, whereas one is a Paleozoic dioritic gneiss.

Apatite grains were concentrated by crushing and sieving the samples, followed by hydrodynamic, magnetic, and heavy-liquid separations. Apatites were embedded in epoxy resin, polished in order to expose internal surfaces within the grains, and the spontaneous fissiontracks were revealed by etching with $5 \mathrm{~N} \mathrm{HNO}_{3}$ at $20^{\circ} \mathrm{C}$ for $20 \mathrm{~s}$. Mounts were then coupled with a low-uranium fission-track-free muscovite mica sheet (external detector method) and sent for irradiation with thermal neutrons at the Radiation Center of Oregon State University (see Donelick et al., 2005, for details). Nominal fluence of $9 \times 10^{15} \mathrm{n} \mathrm{cm}^{-2}$ was monitored using a CN5 uranium-doped silicate glass dosimeter. Induced fission tracks were revealed by etching of the mica sheets in $40 \% \mathrm{HF}$ for $45 \mathrm{~min}$ at 20

${ }^{\circ} \mathrm{C}$. Spontaneous and induced fission tracks were counted under an optical microscope at x1250 magnification, using an automated stage and a digitizing tablet.

Fifteen samples yielded apatites suitable for AFT dating (Table 1). Central ages were calculated using the zeta calibration approach (Hurford and Green, 1983), using Durango (31.3 $\pm 0.3 \mathrm{Ma}$ ) and Fish Canyon Tuff (27.8 $\pm 0.2 \mathrm{Ma})$ age standards within grains exposing caxis-parallel crystallographic planes. Track-length distributions were calculated by measuring horizontal confined tracks together with the angle between the track and the c-axis of the apatite crystal. Confined tracks constitute a small portion of all the AFT populations, therefore additional con-centrates were mounted, polished, and etched for analysis. Ultimately, five samples provided statistically significant numbers of confined tracks for a robust inverse modelling.

Six samples, which yielded the best apatite grains (euhedral, inclusion-free crystals with widths $>60 \mu \mathrm{m}$ ), were selected for $\mathrm{AHe}$ analyses (Table 2). Three to five apatite grains for each sample were hand-picked, photographed, and measured before being wrapped into
$0.8 \mathrm{~mm} \mathrm{Nb}$ tubes. They were then degassed with a Nd-YAG laser and after cryogenic purification ${ }^{4} \mathrm{He}$ was measured by quadrupole mass spectrometry. The concentrations of $\mathrm{U}, \mathrm{Th}$ and $\mathrm{Sm}$ were measured using an inductively coupled plasma mass spectrometer (ICP-MS). Standard procedures are described in Reiners et al. (2004). The alpha ejection correction has been applied to the obtained AHe ages, to take into ac-count the partial He loss due to decay within $20 \mu \mathrm{m}$ of the crystal edge (Farley, 2002; Farley et al., 1996).

\subsection{Modelling procedures}

Five samples from our dataset contained enough confined tracks for a statistically robust inverse modelling: four from the ATFTB (TU279, TU486, TU488 and TU510) and one from the Khrami Massif (TU515) (Table 1). Modelling was performed using the HeFTy software (Ketcham, 2005). Fission-track length and age data were used as input. For all models, Ketcham et al. (2007) annealing model was employed and the Dpar was chosen as kinetic parameter. For sample TU486 it was possible to model AFT and AHe data together. In that case, two replicates (out of four) have been integrated singularly into the model, choosing the two youngest grains because of their concordance. The RDAAM kinetic model (Flowers et al., 2009) was employed for AHe modelling, with alpha correction according to Ketcham et al. (2011). All relevant geological constraints (intrusion/depositional ages, indepen-dent geochronological ages, stratigraphic relationships) were incorpo-rated into the modelling. These constraints are shown as rectangles in the time-temperature plots (Figs. 5, 6, 7 and 8). If no clear-cut infor-mation was available, we used broad $\mathrm{t}-\mathrm{T}$ boxes in order to avoid any forcing. Specific parameters and constraints used for each modelling, compiled according to the protocol of Flowers et al. (2015), are reported in Table S1 (Supplementary Materials).

\section{Analytical results}

Tables 1 and 2 and Fig. 2 provide a summary of the AFT and AHe dataset. The majority $(>86 \%$ ) of the AFT central ages cluster between 47 and $27 \mathrm{Ma}$ (Middle Eocene-Early Oligocene; Table 1). There are only two outliers with respect to this trend: samples TU481 from the ATFTB and TU354 from the Khrami Massif, which yielded central ages of 15.2 \pm 2.7 (Miocene) and 65.2 $\pm 1.3 \mathrm{Ma}$ (Early Paleocene), respectively. All sam-ples passed the $\chi^{2}$ statistical test indicating a single population of grains. There is no correlation between sample ages and elevations (Table S3).

Apatite (U-Th)/He data are shown in Table 2, including single-grain ages of the replicates and the error-weighted mean ages. Errorweighted mean ages (henceforth mean ages) are shown in Fig. 2. Clearly, the mean age is representative only if single-grain age dispersion is low.

AHe mean ages range from $9.5 \pm 0.2$ (Late Miocene) to $3.7 \pm 0.02 \mathrm{Ma}$ (Pliocene) and single-grain ages from 17.3 to $2.6 \mathrm{Ma}$ (Middle Miocene to Pliocene). Generally, the dispersion of single-grain ages is low, except for TU486 ( 17 to $4 \mathrm{Ma}$ ). Single-grain ages of this sample increase with grain radius (although not linearly, Table 1), which could explain the overdispersion. An alternative explanation could be the presence of micro-inclusions of U-rich phases in the oldest crystals which were not recognized during picking. Results from two replicates were discarded: replicate TU486-2 due to a very low eU value coupled with negative count of ${ }^{235} \mathrm{U}$ ppm and replicate TU499-1 due to a negative age. None of the samples analysed showed any clear correlation between crystals age and $\mathrm{eU}$, grain radius (apart from TU486), U or Th content (Table S2a-f). There is no relationship between age and elevation (Table S3).

AFT central ages provide meaningful information from a geological viewpoint if the sample experienced fast cooling through the PAZ but can be misleading if the sample resided within the PAZ for a long time or has experienced moderate reheating at temperatures lower than 120 ${ }^{\circ} \mathrm{C}$. More complete thermochronological constraints can be obtained through statistical modelling of fission-track length distributions. Simi-larly, AHe ages can be biased by a long residence time within the PRZ as 
Table 1

Results of apatite fission-track analyses (see Fig. 2 for location of samples).

\begin{tabular}{|c|c|c|c|c|c|c|c|c|c|c|c|c|c|c|c|c|c|c|}
\hline Sample & Rock Type & Age & Location & $\begin{array}{l}\text { Elevation } \\
(\mathrm{m})\end{array}$ & UTM Coordinates & $\begin{array}{l}\text { No. } \\
\text { crystals }\end{array}$ & $\begin{array}{l}\text { Spont } \\
\rho_{s} N_{s}\end{array}$ & & $\begin{array}{l}\text { Induced } \\
\rho_{i} N_{i}\end{array}$ & $d P\left(x^{2}\right)$ & Dosime & $\begin{array}{l}\text { ter Age } \\
\rho_{d}\end{array}$ & $\frac{(M a)}{N_{d}}$ & $\pm s . d$. & $\begin{array}{l}\text { MCTL }(\mu m) \pm \\
\text { standard error }\end{array}$ & $\begin{array}{l}\text { Standard } \\
\text { deviation }\end{array}$ & $\begin{array}{l}\text { No. tracks } \\
\text { measured }\end{array}$ & Dpar \\
\hline$T U 278^{a}$ & Granite & Late Paleozoic & $\begin{array}{l}\text { Dzirula } \\
\text { Massif }\end{array}$ & 867 & $\begin{array}{l}38 \text { T } 0374158 \\
4658977\end{array}$ & 14 & 2.17 & 36 & 1.03 & 879 & 50.30 & 14.00 & 4459 & $46.9 \pm 5.2$ & - & - & - & - \\
\hline$T U 279^{a}$ & Syenite & Middle Eocene & $\begin{array}{l}\text { Western } \\
\text { ATFTB }\end{array}$ & 334 & $\begin{array}{l}38 T 0260294 \\
4641212\end{array}$ & 17 & 4.99 & 262 & 3.27 & 1716 & 95.52 & 13.00 & 4438 & $33.1 \pm 2.7$ & $13.41 \pm 0.12$ & 1.43 & 50 & 2.10 \\
\hline$T U 281^{a}$ & Diorite & Middle Eocene & $\begin{array}{l}\text { Western } \\
\text { ATFTB }\end{array}$ & 376 & $\begin{array}{l}37 T 0747431 \\
4607962\end{array}$ & 8 & 1.73 & 37 & 1.91 & 409 & 99.19 & 10.01 & 4298 & $15.2 \pm 2.7$ & - & - & - & - \\
\hline$T U 282^{a}$ & Sandstone & Paleocene & $\begin{array}{l}\text { Central } \\
\text { ATFTB }\end{array}$ & 813 & $\begin{array}{l}38 \text { T } 0368846 \\
4636796\end{array}$ & 14 & 1.34 & 76 & 0.70 & 197 & 58.30 & 14.00 & 4432 & $37.5 \pm 5.6$ & - & - & - & - \\
\hline$T U 354^{b}$ & Granitoid & Late Paleozoic & $\begin{array}{l}\text { Khrami } \\
\text { Massif }\end{array}$ & 1524 & $\begin{array}{l}38 T 0426185 \\
4599082\end{array}$ & 21 & 3.40 & 175 & 1.09 & 540 & 99.83 & 9.80 & 4491 & $65.2 \pm 1.3$ & - & - & - & - \\
\hline TU486 & Sandstone & $\begin{array}{l}\text { latest Paleocene-Early } \\
\text { Eocene }\end{array}$ & $\begin{array}{l}\text { Eastern } \\
\text { ATFTB }\end{array}$ & 883 & $\begin{array}{l}38 \div 0456357 \\
4599540\end{array}$ & 49 & 0.14 & 290 & 0.81 & 1691 & 99.68 & 12.22 & 7638 & $34.7 \pm 2.8$ & $12.05 \pm 0.22$ & 1.66 & 53 & 2.38 \\
\hline TU487 & Sandstone & Late Eocene & $\begin{array}{l}\text { Eastern } \\
\text { ATFTB }\end{array}$ & 932 & $\begin{array}{l}38 T 0452684 \\
4611098\end{array}$ & 38 & 0.10 & 107 & 0.69 & 725 & 99.56 & 12.15 & 7593 & $29.3 \pm 3.4$ & - & - & - & 2.51 \\
\hline$T U 488$ & Sandstone & Late Oligocene & $\begin{array}{l}\text { Eastern } \\
\text { ATFTB }\end{array}$ & 1391 & $\begin{array}{l}38 T 0452009 \\
4616299\end{array}$ & 41 & 0.14 & 192 & 1.05 & 1393 & 99.44 & 12.07 & 7547 & $27.3 \pm 2.5$ & $12.48 \pm 0.31$ & 2.26 & 53 & 2.36 \\
\hline TU489 & Sandstone & Late Eocene & $\begin{array}{l}\text { Eastern } \\
\text { ATFTB }\end{array}$ & 1291 & $\begin{array}{l}38 T 0461429 \\
4612640\end{array}$ & 13 & 0.09 & 36 & 0.53 & 224 & 97.20 & 12.00 & 7502 & $31.9 \pm 5.9$ & - & - & - & 2.35 \\
\hline TU490 & Sandstone & Late Eocene & $\begin{array}{l}\text { Eastern } \\
\text { ATFTB }\end{array}$ & 1322 & $\begin{array}{l}38 T 0472584 \\
4613551\end{array}$ & 18 & 0.14 & 55 & 0.58 & 231 & 99.97 & 9.73 & 5046 & $35.5 \pm 5.6$ & - & - & - & 2.46 \\
\hline TU501 & Sandstone & Middle Eocene & $\begin{array}{l}\text { Eastern } \\
\text { ATFTB }\end{array}$ & 561 & $\begin{array}{l}38 T 0476497 \\
4631400\end{array}$ & 88 & 0.16 & 574 & 0.64 & 2320 & 99.35 & 11.78 & 7366 & $45.3 \pm 3.1$ & - & - & - & 2.68 \\
\hline TU504 & Sandstone & $\begin{array}{l}\text { Oligocene-Early } \\
\text { Miocene }\end{array}$ & Kura Basin & 396 & $\begin{array}{l}38 \text { T } 0500933 \\
4602375\end{array}$ & 61 & 0.15 & 333 & 0.81 & 1770 & 99.98 & 11.64 & 7276 & $34.2 \pm 2.6$ & - & - & - & 2.56 \\
\hline TU505 & Sandstone & Late Eocene & $\begin{array}{l}\text { Eastern } \\
\text { ATFTB }\end{array}$ & 512 & $\begin{array}{l}38 \text { T } 0500906 \\
4615010\end{array}$ & 48 & 0.24 & 270 & 1.17 & 1307 & 97.99 & 11.57 & 7230 & $37.6 \pm 3.1$ & - & - & - & 2.30 \\
\hline TU510 & Sandstone & Late Eocene & $\begin{array}{l}\text { Central } \\
\text { ATFTB }\end{array}$ & 1022 & $\begin{array}{l}38 T 0343226 \\
4618483\end{array}$ & 56 & 0.28 & 361 & 1.14 & 1473 & 99.80 & 11.42 & 7140 & $46.0 \pm 3.5$ & $13.03 \pm 0.30$ & 2.29 & 58 & 2.50 \\
\hline TU515 & $\begin{array}{l}\text { Gneiss- } \\
\text { diorite }\end{array}$ & $\begin{array}{l}\text { Precambrian-Early } \\
\text { Paleozoic }\end{array}$ & $\begin{array}{l}\text { Khrami } \\
\text { Massif }\end{array}$ & 985 & $\begin{array}{l}38 T 0431453 \\
4600622\end{array}$ & 21 & 0.55 & 288 & 2.37 & 1242 & 37.65 & 11.35 & 7094 & $43.6 \pm 3.7$ & $13.72 \pm 0.21$ & 1.69 & 65 & 2.12 \\
\hline
\end{tabular}

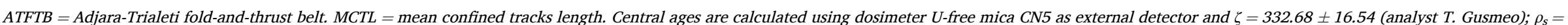

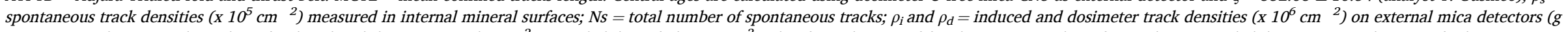

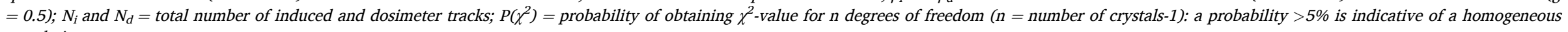
population.

${ }^{a}$ AgesfomAlbinœel(2014)(analystilbino). ${ }^{b}$ Agefrom

Cavazzæal.(2019)(analystiAlbino). 
Table 2

Results of apatite (U-Th)/He analyses (see Fig. 2 for location of samples).

\begin{tabular}{|c|c|c|c|c|c|c|c|c|c|c|c|c|c|c|c|c|c|}
\hline Sample & Rock Type & Age & $\begin{array}{l}\text { Elevation } \\
\text { (m) }\end{array}$ & UTM Coordinates (38 T) & Replicate & Corrected age (Ma) & Error (Ma) & $\begin{array}{l}\text { Error } \\
\text { WeigthedE } \\
\text { Age (Ma) }\end{array}$ & $\begin{array}{l}\text { Weighted } \\
\text { Error (Ma) }\end{array}$ & ${ }^{4} \mathrm{He}(\mathrm{mol})$ & & U 238 (ppm) & U 235 (ppm) & Th 232 (ppm) & Sm 147 (ppm) & $\mathrm{eU}$ & $\begin{array}{l}\text { Rs (equivalent } \\
\text { radius, } \mu \mathrm{m} \text { ) }\end{array}$ \\
\hline \multirow[t]{5}{*}{ TU485 } & Sandstone & Early Eocene & 889 & 04723574609370 & TU 485-1 & 5.37 & 0.05 & 3.7 & 0.02 & $8.47 * 10$ & 15 & 8.68 & 0.07 & 69.94 & 39.25 & 25.12 & 44.75 \\
\hline & & & & & TU 485-2 & 3.58 & 0.04 & & & $6.59 * 10$ & 15 & 19.87 & 0.16 & 81.87 & 35.89 & 39.11 & 42.75 \\
\hline & & & & & TU 485-3 & 2.58 & 0.03 & & & $7.95 * 10$ & 15 & 33.50 & 0.27 & 288.22 & 81.36 & 101.24 & 38.51 \\
\hline & & & & & TU 485-4 & 8.24 & 0.09 & & & $1.05 * 10$ & 14 & 14.72 & 0.12 & 50.43 & 15.33 & 26.58 & 42.55 \\
\hline & & & & & TU 485-5 & 7.26 & 0.08 & & & $7.21 * 10$ & 15 & 9.38 & 0.09 & 61.75 & 43.71 & 23.90 & 46.95 \\
\hline \multirow[t]{5}{*}{ TU486 } & Sandstone & latest Paleocene- & 883 & 04563574599540 & TU 486-1 & 5.93 & 0.18 & 6.1 & 0.1 & $4.96 * 10$ & 15 & 10.16 & 0.09 & 23.87 & 24.08 & 15.77 & 46.88 \\
\hline & & Early Eocene & & & TU486-2 & 9.58 & 0.22 & & & $8.89 * 10$ & 15 & 2.0 & -1.3 & 15.6 & 0.9 & 5.7 & 42.10 \\
\hline & & & & & TU 486-3 & 17.32 & 0.16 & & & $4.69 * 10$ & 14 & 10.10 & 0.08 & 24.19 & 10.84 & 15.78 & 55.53 \\
\hline & & & & & TU 486-4 & 13.62 & 0.20 & & & $1.58 * 10$ & 14 & 10.16 & 0.09 & 40.19 & 19.82 & 19.60 & 47.58 \\
\hline & & & & & TU 486-5 & 4.08 & 0.06 & & & $4.55 * 10$ & 15 & 10.62 & 0.09 & 65.57 & 43.20 & 26.03 & 41.83 \\
\hline \multirow[t]{5}{*}{ TU487 } & Sandstone & Late Eocene & 932 & 04526844611098 & TU 487-1 & 10.81 & 0.63 & 6.4 & 0.1 & $4.53 * 10$ & 15 & 6.91 & 0.08 & 39.88 & 29.50 & 16.28 & 38.85 \\
\hline & & & & & TU 487-2 & 5.80 & 0.06 & & & $1.05 * 10$ & 14 & 17.46 & 0.14 & 79.57 & 75.61 & 36.16 & 45.53 \\
\hline & & & & & TU 487-3 & 7.31 & 0.18 & & & $2.67 * 10$ & 15 & 9.20 & 0.10 & 37.49 & 16.87 & 18.01 & 36.91 \\
\hline & & & & & TU 487-4 & 5.10 & 0.13 & & & $3.13 * 10$ & 15 & 16.15 & 0.15 & 64.32 & 54.55 & 31.27 & 35.21 \\
\hline & & & & & TU 487-5 & 8.41 & 0.10 & & & $1.33 * 10$ & 14 & 16.19 & 0.13 & 54.02 & 42.30 & 28.88 & 96.94 \\
\hline \multirow[t]{3}{*}{ TU499 } & Sandstone & Early Eocene & 1338 & 04455444631754 & TU 499-1 & -8.61 & -0.20 & 9.5 & 0.2 & $-1.22 * 10$ & 15 & 2.61 & 0.13 & 21.86 & 1.07 & 7.75 & 37.96 \\
\hline & & & & & TU 499-2 & 8.85 & 0.24 & & & $1.02 * 10$ & 15 & 3.46 & 0.10 & 20.17 & 1.87 & 8.20 & 37.87 \\
\hline & & & & & TU 499-3 & 10.18 & 0.24 & & & $1.34 * 10$ & 15 & 6.77 & 0.15 & 40.35 & 11.07 & 16.25 & 32.19 \\
\hline \multirow[t]{5}{*}{ TU501 } & Sandstone & Middle Eocene & 561 & 04764974631400 & TU 501-1 & 5.89 & 0.06 & 6.5 & 0.04 & $1.13 * 10$ & 14 & 11.67 & 0.09 & 44.51 & 44.45 & 22.13 & 53.27 \\
\hline & & & & & TU 501-2 & 9.95 & 0.16 & & & $5.81 * 10$ & 15 & 8.63 & 0.08 & 40.63 & 29.07 & 18.17 & 39.50 \\
\hline & & & & & TU 501-3 & 8.74 & 0.10 & & & $1.24 * 10$ & 14 & 12.88 & 0.11 & 68.94 & 27.90 & 29.08 & 44.97 \\
\hline & & & & & TU 501-4 & 6.86 & 0.20 & & & $2.08 * 10$ & 15 & 7.30 & 0.09 & 34.11 & 26.01 & 15.32 & 37.75 \\
\hline & & & & & TU 501-5 & 5.46 & 0.07 & & & $3.26 * 10$ & 15 & 11.41 & 0.11 & 58.72 & 32.88 & 25.21 & 38.48 \\
\hline \multirow[t]{5}{*}{ TU512 } & Sandstone & Late Paleocene- & 833 & 03637754631968 & TU 512-1 & 11.73 & 0.16 & 4.1 & 0.03 & $1.38 * 10$ & 14 & 5.86 & 0.05 & 18.99 & 16.72 & 10.32 & 53.21 \\
\hline & & Early Eocene & & & TU 512-2 & 4.37 & 0.10 & & & $1.61 * 10$ & 15 & 8.17 & 0.09 & 43.50 & 19.42 & 18.39 & 36.37 \\
\hline & & & & & TU 512-3 & 9.84 & 0.17 & & & $1.10 * 10$ & 14 & 7.34 & 0.06 & 21.56 & 19.44 & 12.40 & 52.12 \\
\hline & & & & & TU 512-4 & 3.17 & 0.04 & & & $1.96 * 10$ & 14 & 34.19 & 0.26 & 37.23 & 26.06 & 42.94 & 61.11 \\
\hline & & & & & TU 512-5 & 9.56 & 0.28 & & & $1.64 * 10$ & 14 & 8.13 & 0.07 & 24.77 & 13.85 & 13.96 & 57.68 \\
\hline
\end{tabular}

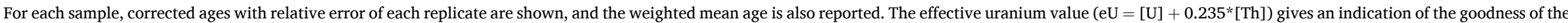
data: if it is lower than 5, than the uranium content of the apatite crystal was too low to provide a meaningful result. The two discarded replicates (TU486-2 and TU499-1) are in italics. 

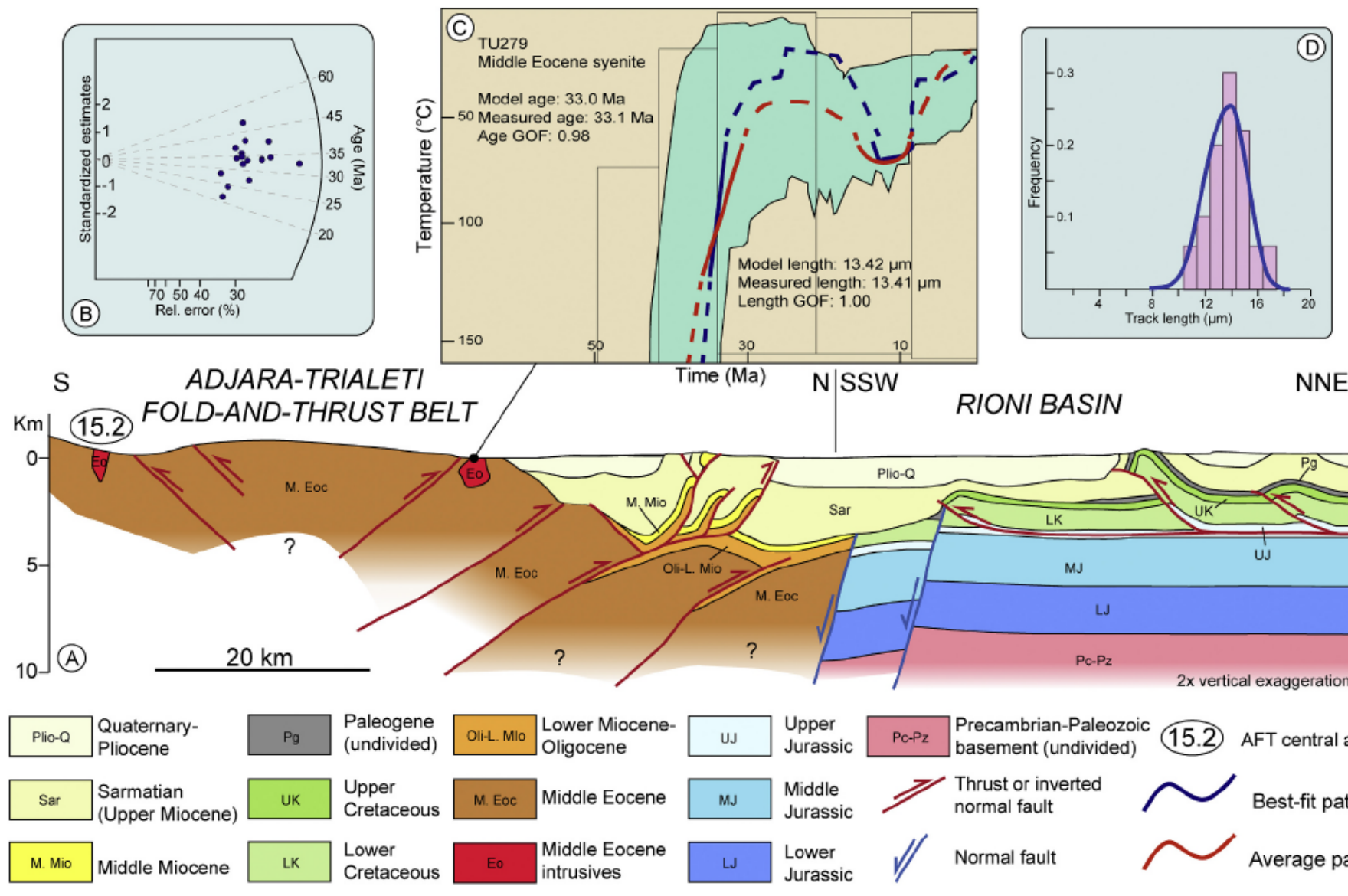

RIONI BASIN

NNE

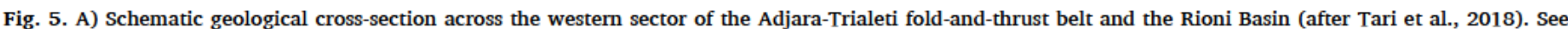

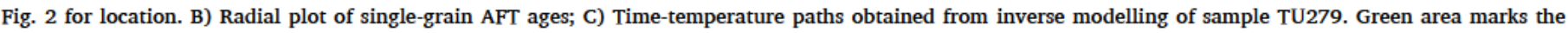

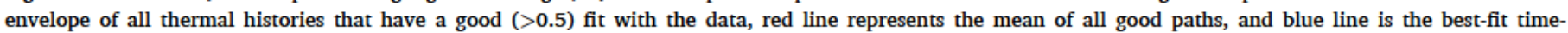

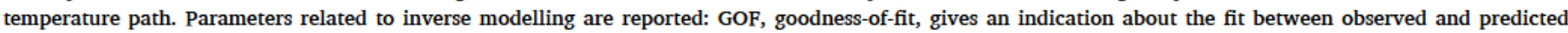

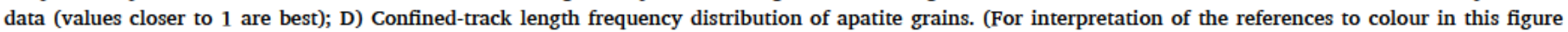
legend, the reader is referred to the web version of this article.)

well as by different He diffusion kinetics. In order to obtain rigorous results, time-temperature modelling was performed integrating all available new and pre-existing data: AFT, (U-Th)/He, other radiometric analyses and stratigraphic relationships. In the following section, the thermochronologic results obtained for the ATFTB and for the Dzirula and Khrami basement salients will be described specifically and inter-preted according to their geological context.

\section{Data interpretation}

\subsection{Adjara-Trialeti fold-and-thrust belt}

AFT central ages from the ATFTB range from 46 to $15 \mathrm{Ma}$ (Middle Eocene-Middle Miocene). Such a relatively long time span from a geologically coherent tectonic element such as the ATFTB depends on the fact that most sandstone samples were never buried enough to reset completely the AFT system. Apatite grains from sedimentary rocks now incorporated within the ATFTB have thus retained a partial memory of the cooling/exhumation history of the original sediment source area. The high $\mathrm{P}\left(\chi^{2}\right)$ values (Table 1 ), corroborated by a check with the binomial peak-fitting program BinomFit (Brandon, 1992), confirm that the samples contain only one population of apatite grains. Partially to non-reset detrital samples containing a single population of grains indicate that they were fed by one thermally coherent source. This point, and its implications for the interpretation of the thermochronologic history of the ATFTB, are discussed below.
AHe ages are consistent, clustering between 10 and $3 \mathrm{Ma}$, with few outliers. Given the lower closure temperature of the apatite (U-Th)/He thermochronometric system $\left(\sim 70{ }^{\circ} \mathrm{C}\right)$, this implies that the re-heating associated with post-depositional sedimentary burial was enough to reset the helium ages. The Late Miocene-Pliocene He ages suggest fast cooling across the partial retention zone (PRZ) of apatite (ca. 40-70 ${ }^{\circ} \mathrm{C}$ ). Following are the low-temperature thermochronology results from the various portions of the ATFTB.

\subsubsection{Western Adjara-Trialeti fold-and-thrust belt}

Several samples were taken from this area but, after processing, only two of them had enough apatite grains. Sample TU279 is a Middle Eocene (43 Ma; U-Pb on zircons, Okrostsvaridze et al., 2018b) syenite (Figs. 2 and 5). Fission-track analysis yielded a central age of $33.1 \pm 2.7 \mathrm{Ma}$ and a mean confined tracks length of $13.41 \pm 0.12 \mu \mathrm{m}$ (Table 1). Track-length distribution is fairly leptokurtic and nearly symmetrical (Fig. 5D). Inverse modelling (Fig. 5C, Table S1a) shows a Middle-to-Late Eocene phase of cooling. This is in line with the commonly held notion that mid-Eocene volcanism and plutonism were largely coeval during the development of the Adjara-Trialeti extensional basin (e.g. Okrosts-varidze et al., 2018a and references therein). The small pluton from which the sample was taken was emplaced at a shallow depth where it cooled quickly, then experienced rather stable temperatures during the Oligocene, minor reheating during the Early-Middle Miocene, and a discrete and fast phase of most likely tectonic cooling/exhumation (see discussion below), starting at around $10 \mathrm{Ma}$ (early Late Miocene). 

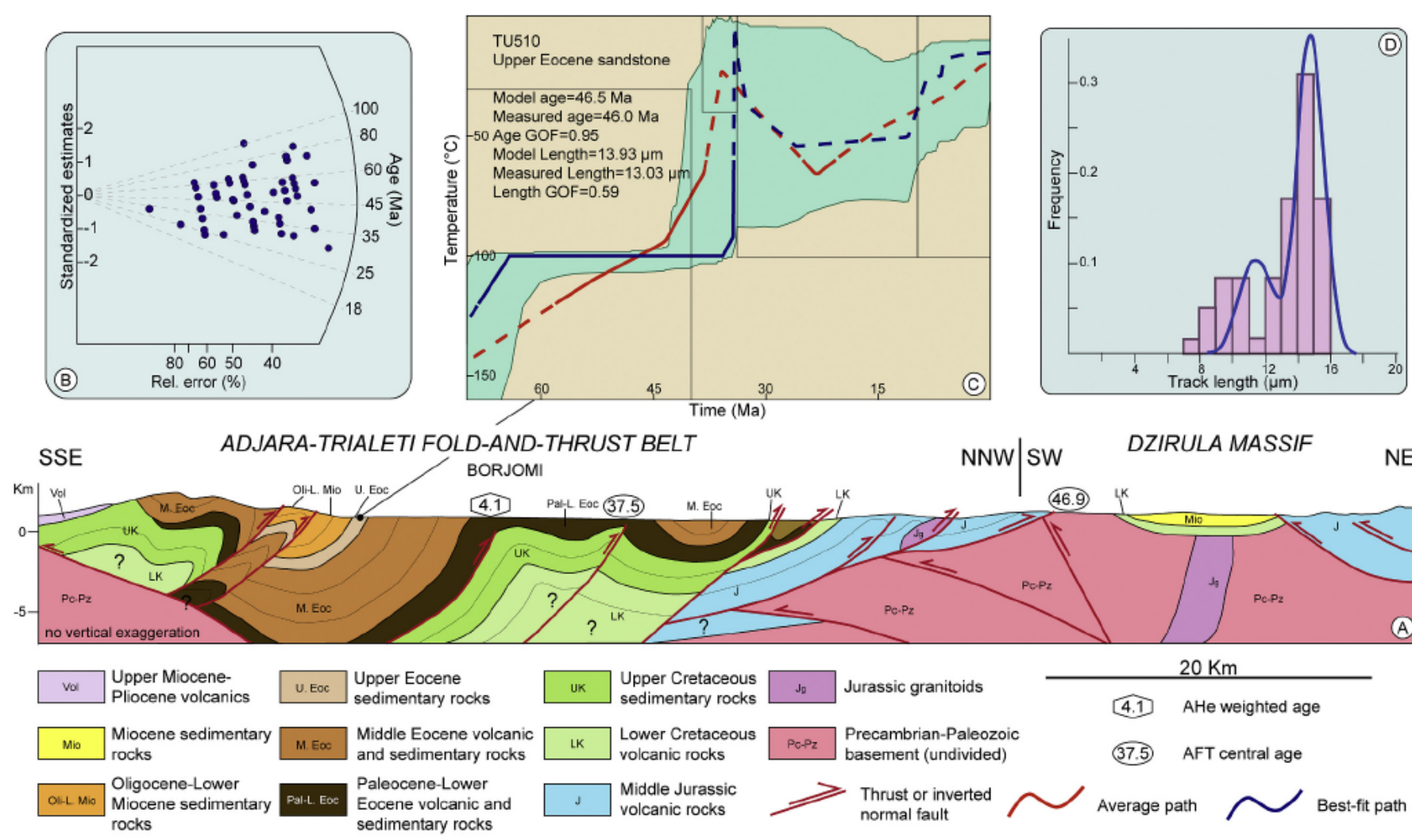

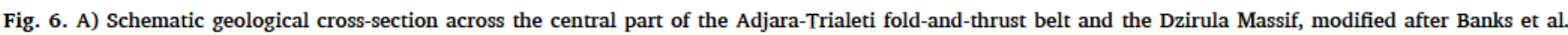

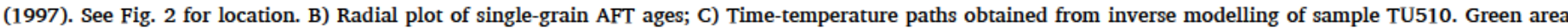

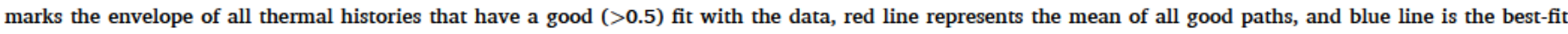

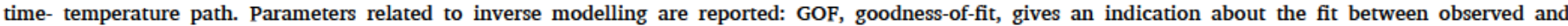

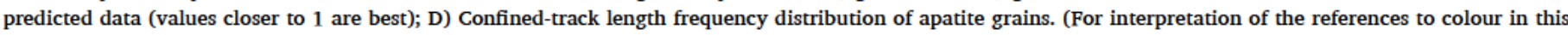
figure legend, the reader is referred to the web version of this article.)

Sample TU281 is a Middle Eocene diorite, $\sim 35 \mathrm{~km}$ south of sample TU279, yielding a central age of $15.2 \pm 2.7 \mathrm{Ma}$, by far the youngest central age of the entire dataset. Zircon U-Pb dating provided the same age as sample TU279, about 43 Ma (Okrostsvaridze et al., 2018b). The Middle Miocene AFT central age of sample TU281 is in line with those available nearby for the easternmost Pontides just across the Turkish border, where mid-Miocene shortening exhumed analogous Eocene plutons (e.g. Kackar Mts.) and brought them to elevations up to ca. $4000 \mathrm{~m}$ (Cavazza and Zattin, 2015).

\subsubsection{Central Adjara-Trialeti fold-and-thrust belt}

Several samples were collected in the antecedent drainage of the Kura River along the Borjomi Valley and in the adjacent areas. Only three of them yielded enough apatite grains for analysis (Figs. 2 and 6; Tables 1 and 2). Sample TU282 is a Paleocene turbidite sandstone (Borjomi Flysch), collected northeast of the town of Borjomi, which yielded a fission-track central age of $37.5 \pm 5.6 \mathrm{Ma}$. Sample TU512 is a sandstone at the Paleocene-Eocene boundary close to Borjomi. It did not contain enough apatites for fission-track analysis, but it was analysed with the helium method. Five replicates from this samples provided corrected helium ages ranging between 11 and $3 \mathrm{Ma}$, indicating that this sample cooled across the He partial retention zone of apatite in the Late Miocene-Pliocene.

Sample TU510 is an Upper Eocene sandstone (about $20 \mathrm{~km} \mathrm{SW}$ of sample TU512). It yielded a central age of $46.0 \pm 3.5 \mathrm{Ma}$ and a mean confined tracks length of $13.03 \pm 0.30 \mu \mathrm{m}$ (Table 1). Track-length frequency distribution is bimodal. Inverse modelling, integrating fissiontrack data and stratigraphic age (Table S1d), indicates some degree of post-depositional reheating (as suggested by the track-length distribution, Fig. 6D). The exact timing of the last episode of cooling is poorly constrained because the sample has not been reheated enough to be reset.

\subsubsection{Eastern Adjara-Trialeti fold-and-thrust belt}

A number of analyses of various samples has provided a fairly detailed picture of the thermochronological evolution of this area. Sample TU499 is a Lower Eocene sandstone from the frontal, northeastern sector of the orogen (Figs. 2 and 7). (U-Th)/He analysis of this sample provided corrected ages of 10 and $8 \mathrm{Ma}$. The low age dispersion indicates that this sample cooled quickly through the He Partial Retention Zone in the Late Miocene.

Sample TU501 is an Upper Eocene sandstone located at the northeastern border of the ATFTB, close to the town of Mtskheta. It provided an AFT central age of $45.3 \pm 3.1$ Ma (Middle Eocene; Figs. 2 and 7), older than the depositional age. Corrected helium ages from five repli-cates range from 10 to $5 \mathrm{Ma}$, with a mean age of $6.5 \pm 0.04$ Ma. Helium single-grain ages are relatively well clustered and indicate cooling through the PRZ in the Late Miocene, while the fission-track central age reflects the age of exhumation of the rocks feeding detritus to the Adjara- Trialeti basin.

Sample TU488 is an Upper Oligocene sandstone taken close to the town of Manglisi (Fig. 2). It yielded a central age of $27.3 \pm 2.5 \mathrm{Ma}$ and a significant number of measurable confined tracks, with a mean length of $12.48 \pm 0.31 \mu \mathrm{m}$ (Table 1). Track-length frequency distribution is bimodal (Fig. 7D). Inverse modelling integrating depositional age and fission-track data (Table S1c) shows predepositional cooling during the Eocene-Early Oligocene, moderate post-depositional heating during progressive burial in the Early Miocene and very fast cooling starting in 

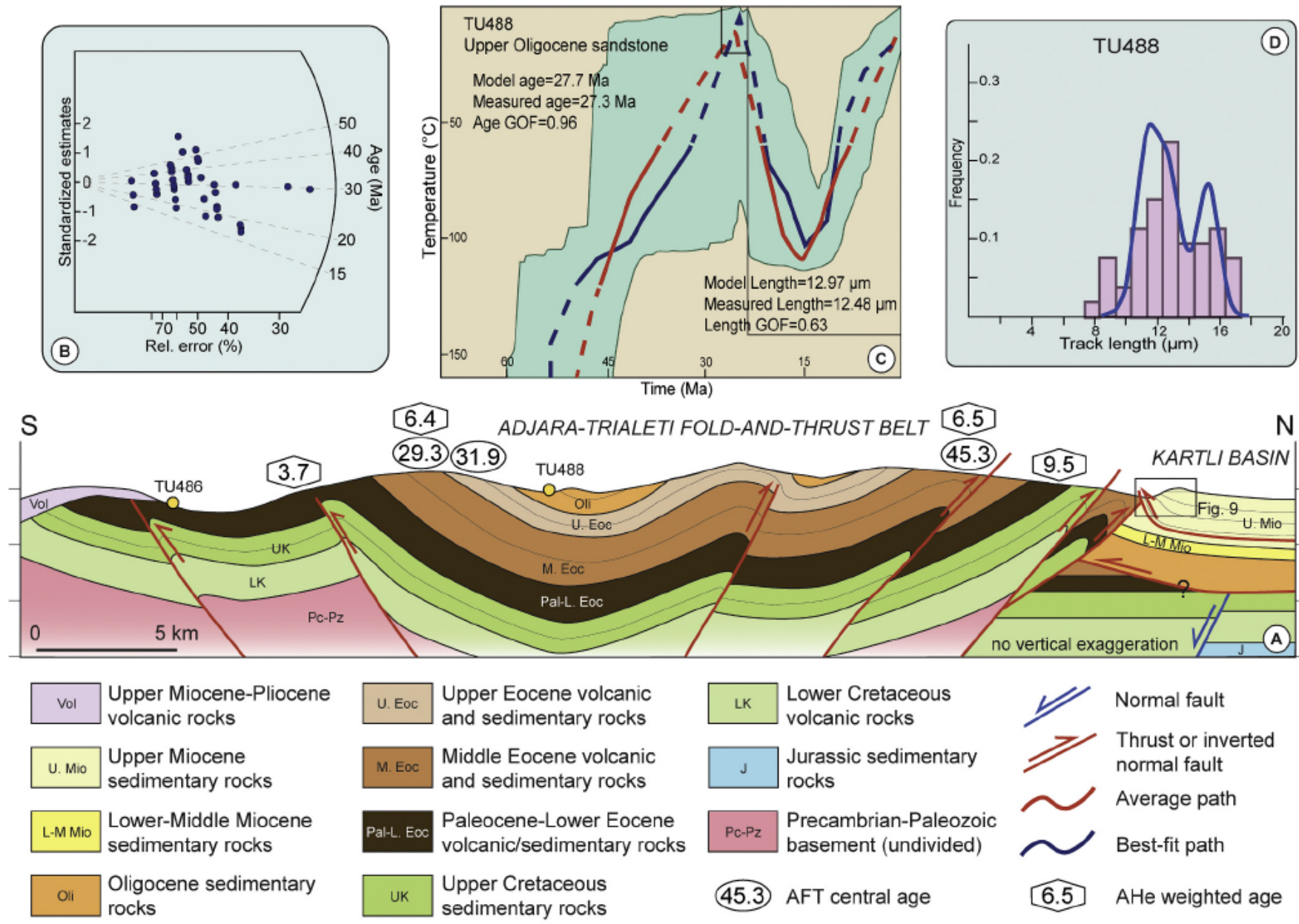

6.4

ADJARA-TRIALETI FOLD-AND-THRUST BELT 6.5 (29.3) (31.9) TU488

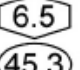

N

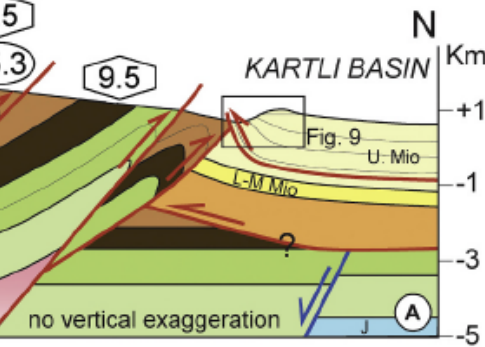

U. Eoc Upper Eocene volcanic
and sedimentary rocks

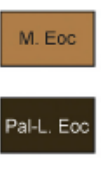

UK
Middle Eocene volcanic and sedimentary rocks

Paleocene-Lower Eocene volcanic/sedimentary rocks Upper Cretaceous sedimentary rocks
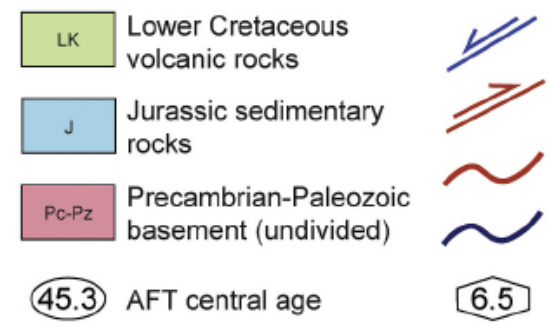

Normal fault

Thrust or inverted normal fault

$\sim$ Average path

$\sim$ Best-fit path

6.5 AHe weighted age
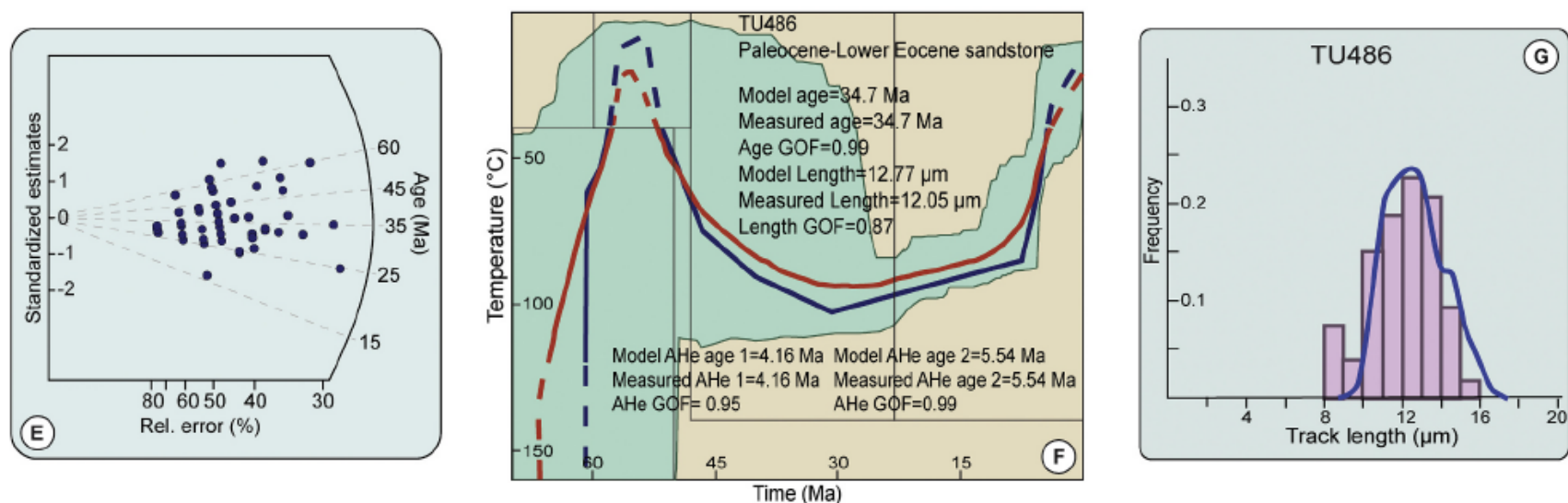

Fig. 7. A) Schematic geological cross-section across the eastern sector of the Adjara-Trialeti fold-and-thrust belt, interpreted from seismic and surface data. See Fig. 2 for location. B) Radial plot of single-grain AFT ages of sample TU488; C) Time-temperature paths obtained from inverse modelling of sample TU488. Green area marks the envelope of all thermal histories that have a good $(>0.5)$ fit with the data, red line represents the mean of all good paths, and blue line is the best-fit time- temperature path. Parameters related to inverse modelling are reported: GOF, goodness-of-fit, gives an indication about the fit between observed and predicted data (values closer to 1 are best). D) Confined-track length frequency distribution of apatite grains of sample TU488; E) Radial plot of single-grain AFT ages of sample TU486; F) Time-temperature paths obtained from inverse modelling of sample TU486; G) Confined-track length frequency distribution of apatite grains of sample TU486. (For interpretation of the references to colour in this figure legend, the reader is referred to the web version of this article.)

the Middle Miocene (14-13 Ma; Fig. 7C).

Five other samples from the eastern ATFTB were analysed but did not yield a sufficient number of confined tracks for inverse modelling. Sample TU487 is an Upper Eocene sandstone which yielded a AFT central age of $29.3 \pm 3.4 \mathrm{Ma}$ and AHe corrected ages between 10 and $5 \mathrm{Ma}$. This rock cooled through the He PRZ of apatite in the Late Miocene and experienced a thermal history similar to the ones of samples TU488 and TU486 (see below and Fig. 7).

Sample TU489 is an Upper Eocene sandstone that yielded a central age of $31.9 \pm 5.9 \mathrm{Ma}$. Sample TU490 is an Upper Eocene sandstone collected at Mount Didgori and yielded a AFT central age of $35.5 \pm$ $5.6 \mathrm{Ma}$. Sample TU504 is an Oligocene-Lower Miocene sandstone which yielded a fission-track central age of $34.2 \pm 2.6$ Ma. Sample TU505 provided an apatite fission-track central age of $37.6 \pm 3.1 \mathrm{Ma}$. Samples 


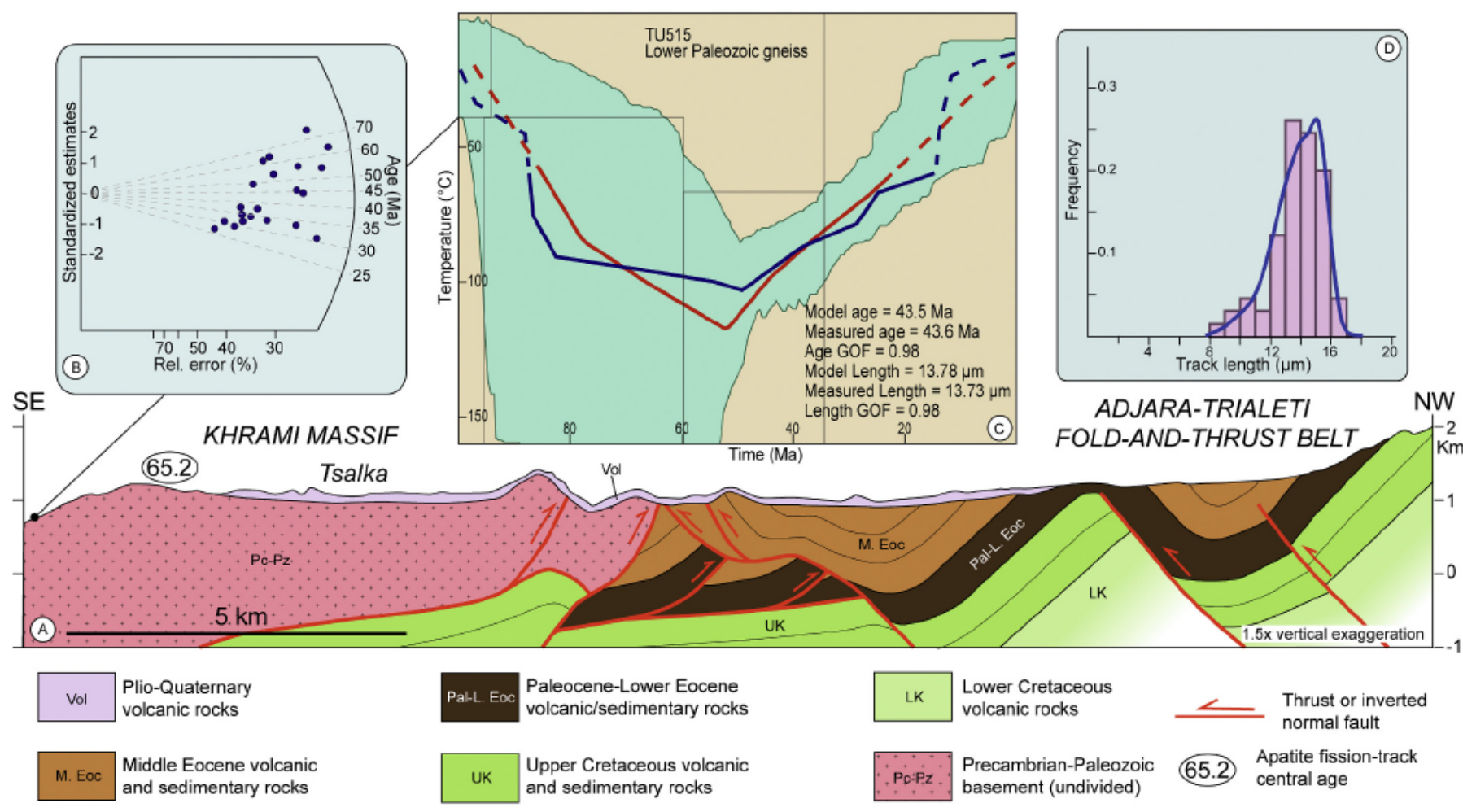

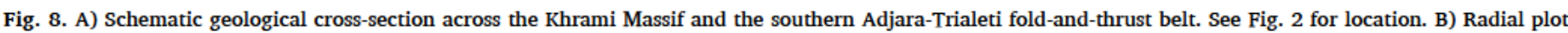

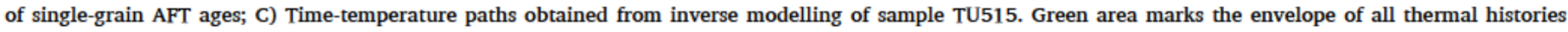

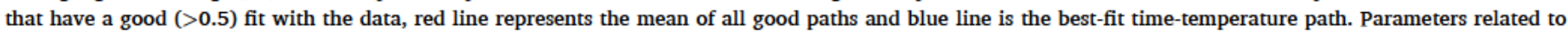

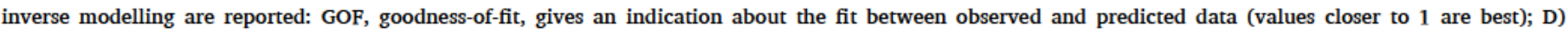

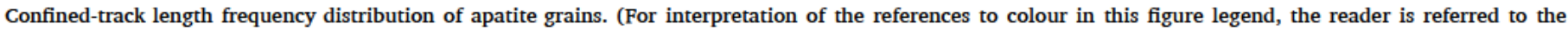
web version of this article.)

TU504 and TU505 were collected from the easternmost portion of the ATFTB, east of Tbilisi (Fig. 2).

Sample TU485 is a Lower Eocene sandstone collected close to the town of Asureti (Figs. 2 and 7). Corrected AHe ages obtained from five replicates range from 8 to $2 \mathrm{Ma}$, indicating that this sample cooled across the PRZ in Late Miocene-Pliocene times.

Sample TU486 is a sandstone dated at the Paleocene-Eocene boundary from the southern border of eastern ATFTB (Figs. 2 and 7). It yielded a central age of $34.7 \pm 2.8 \mathrm{Ma}$ and a mean confined tracks length of $12.05 \pm 0.22 \mu \mathrm{m}$. Track-length frequency distribution is platykurtic (Fig. 7G). Corrected AHe ages from four replicates range from 17 to $4 \mathrm{Ma}$. The reconstructed t-T path of this sample is similar to that of sample TU488, ca. $20 \mathrm{~km}$ to the north (modelling details in Table S1b). Integration of fission-track, helium, and stratigraphic data defines a post-depositional t-T path characterized by moderate burial during the Eocene-Early Oligocene followed by very rapid cooling starting at about $10 \mathrm{Ma}$ (Fig. 7F). The pre-depositional history, although far from clear, points to cooling/exhumation of the sediment source area in the Paleocene-Early Eocene.

\subsection{Dzirula Massif}

Sample TU278 is a Variscan granite from the eastern side of the Dzirula Massif (Figs. 2 and 6), a Neoproterozoic gneiss-migmatitic complex associated with Lower Paleozoic ophiolites intruded and metamorphosed in the Carboniferous by Variscan granitoids (Adamia et al., 2011; Banks et al., 1997). This sample yielded an AFT central age of $46.9 \pm 5.2 \mathrm{Ma}$. The number of horizontally confined tracks was insufficient to perform inverse modelling, hence we can only make suppositions about the significance of this central age, based on geological constraints and other thermochronological data from the literature.

The Dzirula metamorphic salient had already been at the surface in the Mesozoic, as shown by (i) thin mid-Jurassic volcanics and Lower Cretaceous sedimentary rocks nonconformably overlying the basement complex and unconformably separated one from the other (Adamia et al., 2011; Banks et al., 1997; Mayringer et al., 2011; Rolland et al., 2016) and (ii) the results of AFT thermochronometric modelling indicating that the Dzirula basement rocks cooled at temperatures below ${ }^{6} \mathrm{C}$ in the Late Triassic-Late Jurassic (Vincent et al., 2011). The massif was exhumed again during the Paleogene (Vincent et al., 2011). Stratigraphic relationships (Adamia et al., 2011; Banks et al., 1997) indicate that this latter exhumation event occurred sometime between the Middle Paleocene and the Middle Oligocene. The mid-Eocene central age of sample TU278 might be the result of such a cooling event. The presence of a thin (200-400 m) succession of Oligocene-Lower Miocene sandstones and shales unconformably overlying all older units shows that the Dzirula basement complex was exposed at the surface by Late Oligocene time.

\subsection{Khrami Massif}

Sample TU354 is a Late Paleozoic granitoid from the western border of the massif, yielding an AFT central age of $65.2 \pm 1.3 \mathrm{Ma}$ (Figs. 2 and 8). Sample TU515 is a Lower Paleozoic dioritic gneiss (Tedliashvili, 2013) from a migmatitic complex in the central portion of the salient which yielded a central age of $43.6 \pm 3.7 \mathrm{Ma}$ and a mean confined tracks length of $13.72 \pm 0.21 \mu \mathrm{m}$. Its track-length frequency distribution is platykurtic, showing a long tail of short tracks (Fig. 8D). This distribu-tion indicates a long residence in the partial annealing zone and slow cooling. Inverse modelling of this sample integrated fission-track data and stratigraphic data (Fig. 8C, Table S1e). This sample was close to the 
surface in Cenomanian times, based on Cenomanian sediments onlapping nonconformably the massif. About $2000-2500 \mathrm{~m}$ of Upper Cretaceous-Lower Paleocene limestones and volcanics were then deposited on the basement (Adamia et al., 2017b, 2011, 1992). The reconstructed time-temperature path shows such burial heating followed by slow, steady-state cooling starting in the early Eocene at 55-50 Ma (Fig. 8C). Although perfectly in tune with our results in the ATFTB, the pulse of fast cooling in the best-fit path in the Miocene is unreliable because it is outside the partial annealing zone of apatite $\left(60-120^{\circ} \mathrm{C}\right)$, hence beyond the resolution limit of the method.

\section{Discussion}

\subsection{Tïming of Adjara-Trialeti structural inversion}

The thermochronologic results show that the Adjara-Trialeti backarc basin underwent cooling related to orogenic exhumation starting from the late Middle Miocene. Independent stratigraphic and structural evidence points consistently to a Middle-Late Miocene inception of deformation: (i) growth-strata geometries, structural relationships, and the overall stratigraphy of the adjacent Rioni, Kartli and Kura basins, both in outcrop and in the subsurface (Alania et al., 2017, 2018; Tari et al., 2018); (ii) deformation in the Gurian fold belt, the offshore equivalent of the Adjara-Trialeti orogenic belt in the Eastern Black Sea (Banks et al., 1997; Robinson et al., 1995b; Tari et al., 2018), and along the Georgia-Armenia border at the contact between the ATFTB and the easternmost Anatolian Plateau (Koçyiğit et al., 2001).

The progressive unconformity west of Mtskheta (Fig. 9), in the Kartli foreland basin, bears witness to syntectonic sedimentation in the Late Miocene. This structure is just north of the frontal surface thrust of the ATFTB, which exposes here overturned Middle Eocene volcaniclastic rocks. At this location, Sarmatian (late Middle-to-Late Miocene) shallow marine sediments show an offlap geometry, with dip of beds becoming progressively gentler moving from south to north, and are overlain in onlap by sub-horizontal Meotian-Pontian (latest Miocene) shallow marine-to-continental sediments. Similar structures are present else-where (Alania et al., 2018, 2017) and record the progressive incorpo-ration of the foreland basin proximal portion in the wedge-top depozone (DeCelles and Giles, 1996) in response to the progressive northward advancement of the ATFTB in the Late Miocene.

The vast majority of the Oligocene-to-Middle Miocene sedimentary section of the southern Rioni, Kartli and Kura foreland basins - which have later subsided in response to the progressive growth of the Adjara- Trialeti orogen and have collected the detritus deriving from it - is mostly made of fine-grained siliciclastic rocks. Deposition of coarse- grained syntectonic sandstones and conglomerates, suggesting the proximity of a growing orogenic prism to the south, started from the Late Sarmatian (ca. 10-8 Ma) (Adamia et al., 2010, 2011; Pupp et al., 2018; Sachsenhofer et al., 2018; Tari et al., 2018).

Seismic lines from the Gurian belt offshore western Georgia show a series of northward imbricated blind thrusts flooring into the Maykopian (Oligocene-Lower Miocene) shales and evaporites (Banks et al., 1997). Dramatic thickness variations and synkinematic geometries occur within the Sarmatian section, whereas the overlying Meotian-Pontian section drapes all older structures (Tari and Simmons, 2018).

Further evidence of Miocene tectonism is found along the GeorgiaArmenia border. Here, a thick succession dominated by shallowmarine and fluvio-lacustrine sediments of Late Eocene-Early Miocene age is overlain in angular unconformity by a $>500 \mathrm{~m}$ thick Late Miocene-Early Pliocene volcano-sedimentary sequence consisting of various volcanic rocks alternating with fluvio-lacustrine deposits, preceded by basal conglomerates (Koçyiğit et al., 2001).

Our results are in agreement with paleoenvironmental reconstructions, based on foraminifera and pollen, which indicate that until the Early Sarmatian the region comprised between the Lesser Caucasus to the south and the Greater Caucasus to the north (commonly referred to as Transcaucasia) was covered by the sea. Since the Middle Sarmatian (ca. $10 \mathrm{Ma}$ ) this region became emerged and the connection between the Black Sea and the Caspian Sea was definitely interrupted (Fig. 4), with marine conditions persisting only in the easternmost and westernmost parts of the Kura and Rioni Basin, respectively (Shatilova et al., 2020).

\subsection{Cooling history of the Khrami and Dzirula massifs}

The thermochronometric histories of the Dzirula and Khrami massifs are significantly different from that of the Adjara-Trialeti backarc basin. Integrated thermochronological modelling from the Khrami Massif south of the ATFTB indicates prolonged but shallow burial heating at ca. 100-60 Ma due to the deposition of the Late Cretaceous section over-lying nonconformably the massif. This phase of burial was followed by cooling/exhumation starting in the Early Eocene (Fig. 8). At the surface, the Khrami Massif is largely concealed by a cover of Pliocene volcanic rocks but industrial seismic lines show that the massif is the surficial expression of an out-of-sequence, northvergent basement thrust sheet overlying a structural duplex made of Jurassic-Cretaceous rocks (Alania et al., in prep.). Such an out-ofsequence thrust can be related to Paleocene continental accretion along the Erzinçan-Sevan-Akera suture to the south (e.g. Barrier et al., 2018; Okay and Tüysüz, 1999; Sosson et al., 2010, 2016). Early Eocene, shortening-related cooling of the

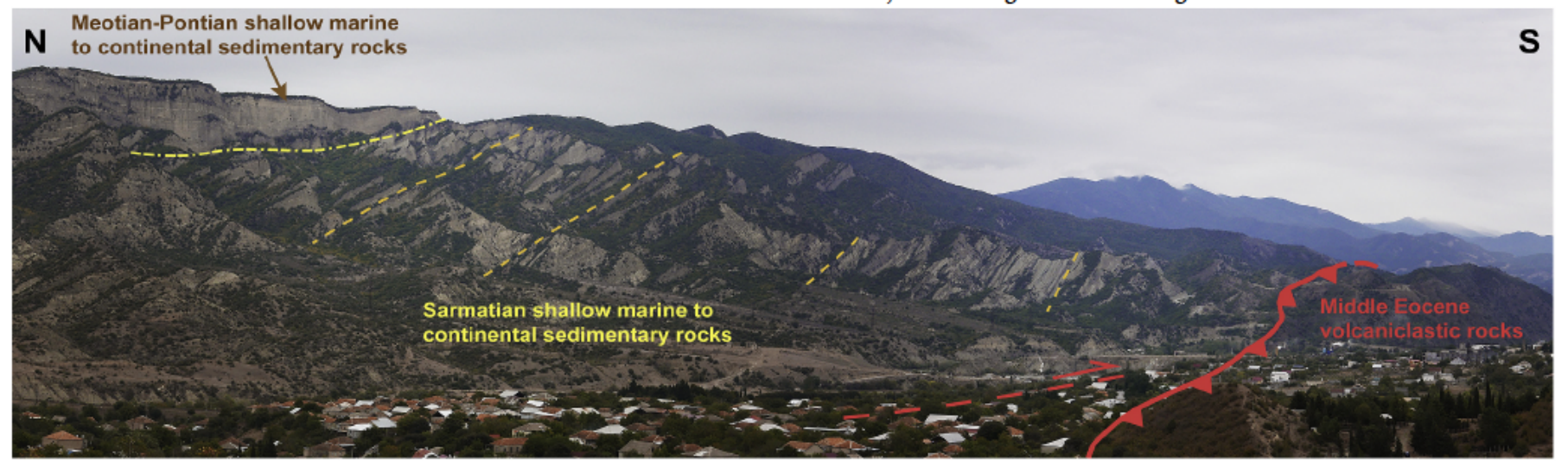

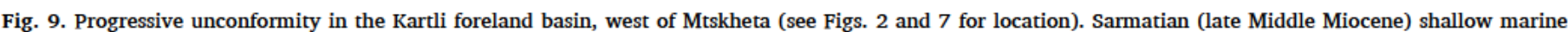

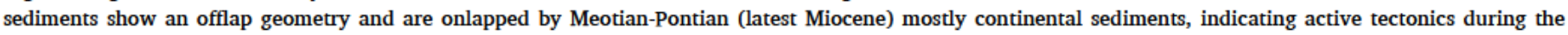
Middle and Late Miocene. 
Khrami Massif occurred soon before the main phase of rift-related subsidence and burial heating of the Adjara-Trialeti back-arc basin fill in the Middle Eocene. Such a situation is characteristic of the hinterland of converging continental margins, where phases of orogenic shortening (including thick-skinned tectonics) along the retroarc fold-and-thrust belt and back-arc extension can alternate and partially overlap in space and time (e.g. Horton et al., 2016).

The Dzirula Massif basement complex cooled at temperatures below $60{ }^{\circ} \mathrm{C}$ in the Late Triassic-Late Jurassic. The massif was exhumed again between the Middle Paleocene and the Middle Oligocene (Vincent et al., 2011), arguably in the Middle Eocene, as suggested by our data (Table 1; Fig. 6). If this were the case, the basement salient should have been affected by cooling while the basin was experiencing subsidence and burial heating. The Dzirula Massif can be tentatively regarded as a portion of the rift shoulders of the former Adjara-Trialeti back-arc basin, because of its position along the northern margin of the ATFTB and because the reconstructed thermal evolution does not support the notion of an Eocene-Oligocene burial/heating, as one would expect if the massif were involved in rift-related subsidence. Basement rocks exposed as rift shoulders during extension probably represented the main source of detrital apatites to the sedimentary fill of the basin because (i) crystal-line rocks have a much higher yield of apatite grains with respect to syn- rift volcanic rocks, the other potential sediment source (Malusà and Garzanti, 2019), (ii) they had been exposed at the surface for a long time, and (iii) their cooling/exhumation history agrees with the partially reset samples of the Adjara-Trialeti. The exact determination of the Adjara-Trialeti syn-rift sediment provenance is worth further investi-gation as the input of a percentage of penecontemporaneous volcanic apatite grains cannot be ruled out.

\subsection{Structural inversion of young rift basins}

Due to their geodynamic setting, thermal state, structural configuration, and density distribution, young extensional sedimentary basins are rheologically weak and susceptible to deformation even by episodic stress-field variations (Cloetingh et al., 2005; Hall et al., 2011; Letouzey et al., 1990; Munteanu et al., 2011; Nikishin et al., 2001; Ziegler, 1990; Ziegler et al., 1995, 1998, 2002). Structural inversion of extensional basins can be produced not only by increased convergence rates along subduction zones (e.g. Funiciello et al., 2008; Heuret et al., 2007; Heuret and Lallemand, 2005) but also during continental collisions and the ensuing indentation, when strong mechanical coupling between the collisional orogenic wedge and its forelands promotes far-field stress transfer and the onset and evolution of intraplate compressional features (Cloetingh et al., 1989; Jolivet et al., 1989; Ziegler, 1993).

Numerical and analogue models identify the duration of the postrift phase as the main factor controlling shortening of a rift basin (Buiter et al., 2009; Ziegler and Cloetingh, 2004) in that structural inversion is facilitated if it occurs within about 25 Ma from the end of the rifting stage, when the lithosphere is still relatively hot. The Adjara-Trialeti back-arc basin underwent a post-rift phase shorter than 25 My, from the Late Eocene to the Middle Miocene (Fig. 4), characterized by the deposition of a post-rift sedimentary cover that blanketed the basin as well as the rift shoulders (Adamia et al., 2011; Banks et al., 1997).

Structural inversion of extensional basins is favoured by a weak lower crust and mainly controlled by the reactivation of pre-existing structural discontinuities (i.e. extensional faults) whereas the inception of new faults that cut through older extensional structures is subordinate (Brun and Nalpas, 1996; Buiter and Pfiffner, 2003; Hooper et al., 1995; Van Wijhe, 1987). The extended continental crust of the Adjara-Trialeti back-arc region was mechanically weaker and hence prone to inversion and reactivation of the extensional faults (Cloetingh et al., 2015, 2003; Munteanu et al., 2013, 2011; Roure, 2008; Ziegler and Cloetingh, 2004) during Miocene compression. Structural inversion was also facilitated by the rheological contrast between the relatively hot and weak rift basin, the strong Dzirula Massif to the north and the more rigid and relatively pristine (quasi)oceanic lithosphere of the adjacent Eastern Black Sea (Munteanu et al., 2013).

Early structural inversion of back-arc rift basins has been recognized in fossil and active orogenic belts, including (i) current inversion of various Miocene rift basins in the eastern margin of the Japan Sea (Kato et al., 2004; Okamura et al., 1995), (ii) Late Paleozoic intra-continental rifting and inversion of the Yamansu belt of NW China (Jiang et al., 2017), (iii) Paleoproterozoic back-arc rifting and inversion of the Kis-seynew belt of central Canada (Ansdell et al., 1995), (iv) the Paleogene half-grabens of the eastern Sunda platform in Indonesia (Letouzey et al., 1990), and (v) the Denison Trough in the Bowen Basin of eastern Australia (Buiter et al., 2009). In many cases, far-field stress trans-mission from continental collision zones has been pointed out as the main cause for compressional reactivation of extensional structures, as in the aforementioned Sunda Platform (Letouzey et al., 1990), the southern North Sea (de Lugt et al., 2003; Nalpas et al., 1995), the Pan-nonian Basin (Bada et al., 2007a, 2007b; Cloetingh et al., 2006; Horváth et al., 2006), and the BalkanidesWestern Black Sea (Munteanu et al., 2013, 2011). In all these examples, the end of extension and the beginning of inversion were separated by a relatively short time span $(<25 \mathrm{Ma})$ and extensional structures perpendicular to stress direction were reactivated as contractional faults. The results of this study indi-cate that inversion of the Adjara-Trialeti back-arc basin occurred ca. $20 \mathrm{Ma}$ after the cessation of rifting. The E-W-striking normal faults bounding the Adjara-Trialeti basin were broadly perpendicular to the overall convergence direction between the colliding Arabian and Eurasian plates (Barrier et al., 2018; Barrier and Vrielynck, 2008) and thus particularly prone to reactivation by inversion.

\subsection{Evolution of the Adjara-Trialeti FTB in the geodynamic context of the Middle East}

The opening of the Adjara-Trialeti back-arc basin can be viewed as a late stage development of a wide and largely diachronous Late Cretaceous-Eocene regional extensional domain stretching -west to east- from the Srednogorie rift zone of eastern Bulgaria (Bergerat et al., 2010; Boccaletti et al., 1978; Georgiev et al., 2001), across the Black Sea, to the Adjara-Trialeti basin studied here. This extensional region developed along the southern Eurasian margin during northward subduction of the northern branch of the Neotethys (Barrier et al., 2018; Barrier and Vrielynck, 2008; Stampfli and Hochard, 2009).

Considering the uncertainties on the timing of opening of the eastern Black Sea, it is still unclear whether the Adjara-Trialeti basin (whose volcano-sedimentary fill is now deformed into the ATFTB) is to be considered as (i) the direct eastward onshore prolongation of the Black Sea or (ii) part of an E-W elongate extensional domain right behind the Pontide magmatic arc, as shown in Fig. 4 (cf. Adamia et al., 2017b; Banks et al., 1997; Lordkipanidze et al., 1979; Nikishin et al., 2011; Robinson et al., 1995a, 1995b; Shillington et al., 2008; Spadini et al., 1996). Whatever the exact timing, the Eastern Black Sea and the Adjara- Trialeti basins underwent extension because of the same overall geo-dynamic process, i.e. rollback during northward subduction of the northern Neotethyan slab (Banks et al., 1997; Barrier et al., 2018). The Eastern Black Sea rift reached a (quasi)oceanic stage (Nikishin et al., 2015b, 2015a; Shillington et al., 2008) whereas Adjara-Trialeti rifting stopped before oceanic crust was formed, despite the emplacement of large volumes of lavas, particularly in the western part of the basin.

In our Danian reconstruction (Fig. 4), the Adjara-Trialeti region is undergoing flexural subsidence due to the continental collision between the Anatolide-Tauride terrane and the Pontide magmatic arc, as previ-ously pointed out in the geological background. Back-arc rifting began in the Eocene (Adamia et al., 2011, 1981, 1977; Okrostsvaridze et al., 2018a, 2018b; Gamkrelidze et al., 2019), when advanced docking of the Anatolide-Tauride-Armenian terrane into the southern Eurasian margin induced roll-back of the northern Neotethyan slab and extension in the upper plate (e.g. Barrier et al., 2018; Barrier and Vrielynck, 2008). 
The low-temperature thermochronologic evolution of the AdjaraTrialeti back-arc basin during the Neogene, with particular reference to Miocene cooling, mirrors the results of thermochronometric studies in adjacent regions. An important and discrete phase of cooling/ exhuma-tion in the mid-Miocene occurred in the Bitlis-Pütürge collision zone, i.e. the area of maximum indentation between the colliding Arabian and Eurasian plates (Cavazza et al., 2018; Okay et al., 2010). Coevally, the hinterland of this collision zone, particularly the Eastern Pontides of eastern Turkey and the Lesser Caucasus of Armenia and Azerbaijan, was subjected to fault reactivation, shortening, and exhumation (Albino et al., 2014; Cavazza et al., 2019) (Fig. 10). Regional shortening during the Middle Miocene has been reported also in the Alborz, Zagros and Talysh ranges (Axen et al., 2001; Ballato et al., 2016, 2008; Barber et al., 2018; Gavillot et al., 2010; Madanipour et al., 2017) while fast uplift has been recognized in the Greater Caucasus starting at ca. $10 \mathrm{Ma}$ (Avdeev and Niemi, 2011; Mosar et al., 2010; Vasey et al., 2020; Vincent et al., 2020). The late Middle Miocene-Pliocene structural inversion of the Adjara-Trialeti back-arc basin documented in this paper and the coeval synsedimentary deformation within the Kura and Rioni foreland basins (Alania et al., 2017; Tibaldi et al., 2017) can be also interpreted as an effect of far-field stress transmission from the ArabiaEurasia collision zone into the hinterland.

In this paper, we choose not to elaborate on the evolution of the Greater Caucasus as its timing of uplift is a matter of considerable dispute. Vincent et al. (2016, 2013b, 2013a, 2007) propose an early Oligocene age supported by fossil reworking, paleoaltitude data, paleocurrent vectors, and some thermochronologic data. Other authors (e.g. Lozar and Polino, 1997; Nikishin et al., 2017) reached the same conclusion. On the other hand, Rolland (2017), taking into account the geodynamic context and the thermochronologic constraints on the
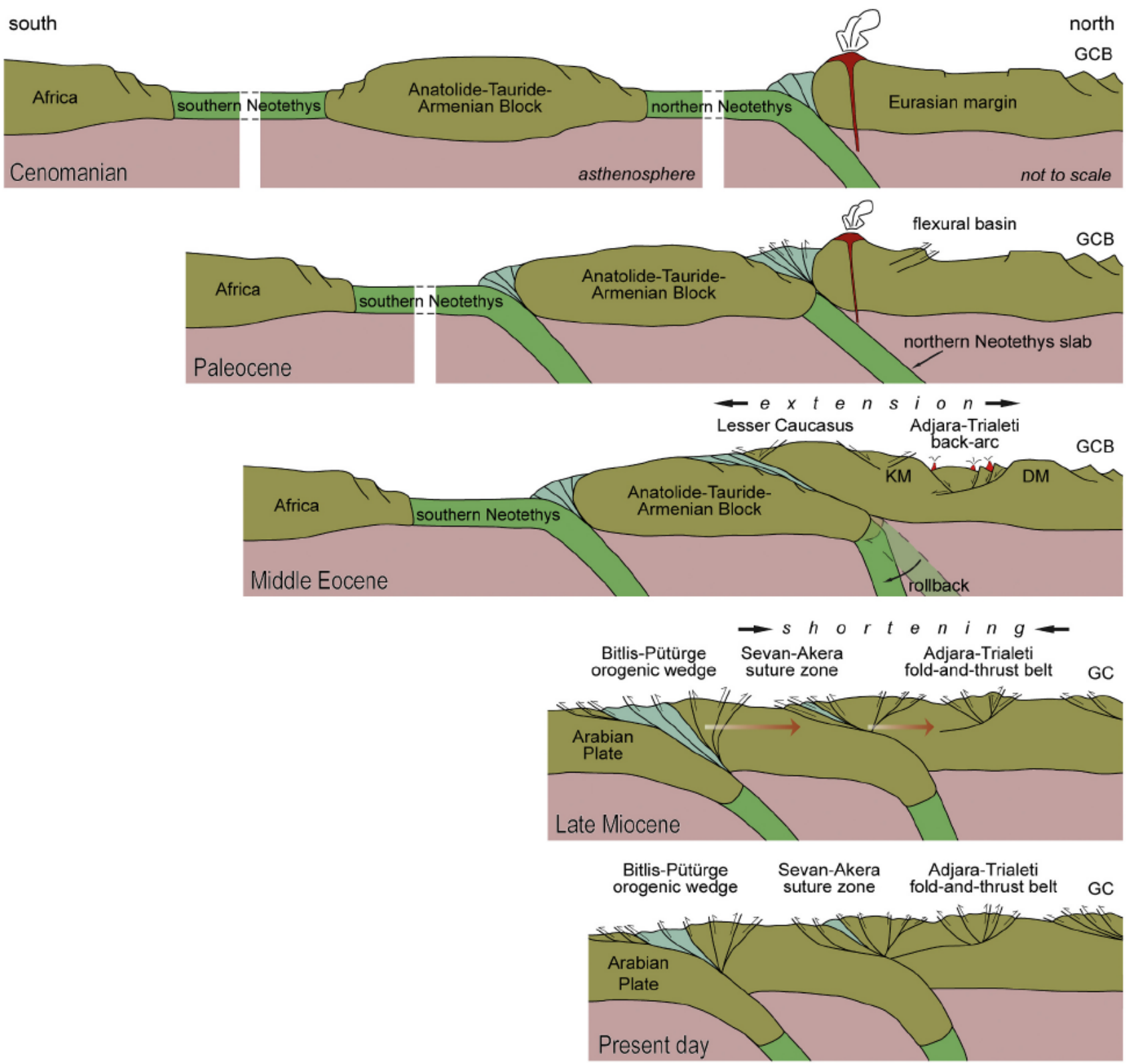

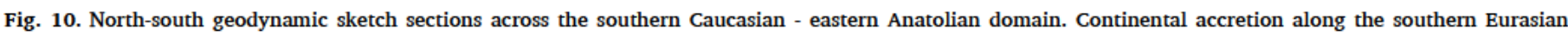

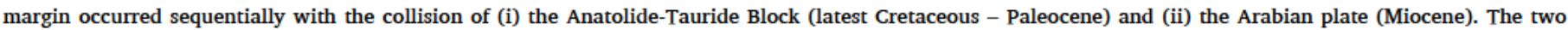

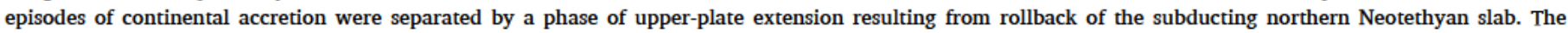

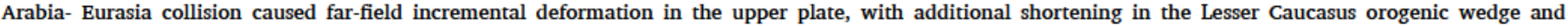
inversion of the Adjara-Trialeti continental back-arc basin. DM = Dzirula Massif; GCB = Greater Caucasus Basin; $\mathrm{KM}=\mathrm{Khrami}$ Massif. 
timing of the Arabia-Eurasia collision (Cavazza et al., 2018; Okay et al., 2010), support a Middle Miocene age for the onset of Caucasus uplift. Lastly, Avdeev and Niemi (2011), Cowgill et al. (2016) and Forte et al. (2014) have proposed that the major phase of uplift occurred no earlier than 5 My ago. Vincent et al. (2020) link the Late Miocene-Pliocene acceleration in exhumation recorded in the Greater Caucasus to a major reorganization of the Arabia-Eurasia collision since $\sim 5 \mathrm{Ma}$ (Allen et al., 2004) and/or to break-off of the hypothesized Greater Caucasus slab (Mumladze et al., 2015). It is evident that more work on the Greater Caucasus is required in order to better constrain its geological evolution and then frame it within the geodynamic context.

7. Conclusions

The main results of this study can be summarized as follows:

8. The Paleogene Adjara-Trialeti rift basin, after a short (ca. $20 \mathrm{Ma}$ ) post-rift stage, was structurally inverted during the Middle MiocenePliocene, starting at 14-10 Ma.

9. Basin inversion can be envisioned as a far-field effect of continued stress transfer produced by the Arabia-Eurasia hard collision, which started in the Middle Miocene along the Bitlis-Pütürge suture to the south and affected preexisting structural discontinuities farther away within the hinterland to the north.

10. The Khrami Massif is the surficial expression of out-of-sequence, north-vergent basement thrusting possibly related to Paleocene continental accretion along the Erzinçan-Sevan-Akera suture to the south, and started being exhumed in the Early Eocene.

11. Back-arc rift basins are sensitive indicators of stress-field variations, not only along subduction zones but also in the hinterland of continental collision zones, where collisional stress can be transmitted and focus along preexisting rheological discontinuities at distances in the order of several hundred kilometres.

\section{Declaration of Competing Interest}

The authors declare that they have no known competing financial interests or personal relationships that could have appeared to influence the work reported in this paper.

\section{Acknowledgments}

We thank Irene Albino (University of Bologna) and Silvia Cattò (University of Padua) for help during data acquisition and interpretation. Sample preparation and AFT analyses were carried out at the Department of Biological, Geological and Environmental Sciences of the University of Bologna. Helium analyses were performed at the Dept. of Neotectonics and Thermochronology of the Czech Academy of Sciences in Prague. Jon Mosar (University of Fribourg) shared his expertise on the regional tectonic framework of the study area. Anatoly M. Nikishin (Moscow State University) and Randell Stephenson (University of Aberdeen) are thanked for their supportive reviews, Stephen J. Vincent (CASP) provided useful comments on an earlier version of the manu-script. This study was funded by PRIN and RFO funds to W. Cavazza and M. Zattin.

\section{Appendix A. Supplementary data}

Supplementary data to this article can be found online at https:// doi. org/10.1016/j.tecto.2020.228702.

\section{References}

Adamia, S.A., 2004. Geological Map of Georgia, 1: 500000 Scale.

Adamia, S.A., Lordkipanidze, M.B., Zakariadze, G.S., 1977. Evolution of an active continental margin as exemplified by the Alpine history of the Caucasus. Tectonophysics 40, 183-199. https://doi.org/10.1016/0040-1951(77)90065-8.
Adamia, S.A., Chkhotua, T., Kekelia, M., Lordkipanidze, M., Shavishvili, I.,

Zakariadze, G., 1981. Tectonics of the Caucasus and adjoining regions: implications for the evolution of the Tethys ocean. J. Struct. Geol. 3, 437-447. https://doi.org/ 10.1016/0191-8141(81)90043-2.

Adamia, S.A., Akhvlediani, K.T., Kilasonia, V.M., Nairn, A.E.M., Papava, D., Patton, D.K., 1992. Geology of the republic of Georgia: a review. Int. Geol. Rev. 34, 447-476.

Adamia, S.A., Mumladze, T., Sadradze, N., Tsereteli, E., Tsereteli, N., Varazanashvili, O., 2008. Late Cenozoic Tectonics and Geodynamics of Georgia (SW Caucasus). Georg. Int. J. Sci. Technol. 1, 77-107. https://doi.org/10.1111/jbi.12174.

Adamia, S.A., Alania, V., Chabukiani, A., Chichua, G., Enukidze, O., Sadradze, N., 2010. Evolution of the late Cenozoic basins of Georgia (SW Caucasus): a review. In: Sosson, M., Kaymakci, N., Stephenson, R.A., Bergerat, F., Starostenko, V. (Eds.), Sedimentary Basin Tectonics from the Black Sea and Caucasus to the Arabian Platform, 340. Geological Society, London, Special Pubblications, pp. 239-259.

Adamia, S.A., Zakariadze, G., Chkhotua, T., Sadradze, N., Tsereteli, N., Chabukiani, A., Gventsadze, A., 2011. Geology of the Caucasus: a Review. Turk. J. Earth Sci. 20, 489-544. https://doi.org/10.3906/yer-1005-11.

Adamia, S.A., Alania, V., Tsereteli, N., Varazanashvili, O., Sadraze, N., Lursmanashvili, N., Gventsadze, A., 2017a. Postcollisional tectonics and seismicity of Georgia. In: Sorkhabi, R. (Ed.), Tectonic Evolution, Collision, and Seismicity of Southwest Asia: In Honor of Manuel Berberian's Forty-Five Years of Research Contributions, 525. Geological Society of America Special Paper, pp. 1-38.

Adamia, S.A., Chkhotua, T.G., Gavtadze, T.T., Lebanidze, Z.A., Lursmanashvili, N.D., Sadradze, N.G., Zakaraia, D.P., Zakariadze, G.S., 2017b. Tectonic setting of Georgia- Eastern Black Sea: A review. In: Sosson, M., Stephenson, R.A., Adamia, S.A. (Eds.), Tectonic Evolution of the Eastern Black Sea and Caucasus, 428. Geological Society, London, Special Publications, pp. 11-40. https:// doi.org/10.1144/SP428.6.

Alania, V., Chabukiani, A.O.. Chagelishvili, R.L., Enukidze, O.V., Gogrichiani, K.O.,
Razmadze, A.N., Tsereteli, N.S., 2017. Growth structures, piggy-back basins and growth strata of the Georgian part of the Kura foreland fold-thrust belt: Implications for late Alpine kinematic evolution. In: Sosson, M., Stephenson, R.A., Adamia, S.A. (Eds.), Tectonic Evolution of the Eastern Black Sea and Caucasus, vol. 428. Geological Society, London, Special Publications, pp. 428-445. https://doi.org/

10.117Z/1010539510370992 2র., Razmadze, A., Chabukiani, A., Giorgadze, A., Vakhtang Glonti, B., Koiava, K., Beridze, T., Khutsishvili, S., Chagelishvili, R., 2018. Structural Architecture of the Kura Foreland Fold-and-thrust Belt using Seismic Reflection Profile, Georgia. Univers. J. Geosci. 6, 184-190. https://doi.org/ 10.13189/ujg.2018.060402.

Albino, I., Cavazza, W., Zattin, M., Okay, A.I., Adamia, S.A., Sadradze, N., 2014. Far-field tectonic effects of the Arabia-Eurasia collision and the inception of the North Anatolian Fault system. Geol. Mag. 151, 372-379. https://doi.org/10.1017/ s0016756813000952.

Allen, M., Jackson, J., Walker, R., 2004. Late Cenozoic reorganization of the ArabiaEurasia collision and the comparison of short-term and long-term deformation rates. Tectonics 23. https://doi.org/10.1029/2003TC001530.

Ansdell, K.M., Lucas, S.B., Connors, K., Stern, R.A., 1995. Kisseynew metasedimentary gneiss belt, Trans-Hudson orogen (Canada): back-arc origin and collisional inversion. Geology 23, 1039-1043. https://doi.org/10.1130/0091-7613(1995) $023<1039$ :KMGBTH $>2.3$.CO;2.

Avdeev, B., Niemi, N.A., 2011. Rapid Pliocene exhumation of the central Greater Caucasus constrained by low-temperature thermochronometry. Tectonics 30, 1-16. https://doi.org/10.1029/2010TC002808.

Axen, G.J., Lam, P.S., Grove, M., Stockli, D.F., Hassanzadeh, J., 2001. Exhumation of the west-central Alborz Mountains, Iran, Caspian subsidence, and collision-related tectonics. Geology 29, 559-562. https://doi.org/10.1130/0091-7613(2001) 029<0559:EOTWCA >2.0.CO;2.

Bada, G., Grenerczy, G., Tóth, L., Horváth, F., Stein, Seth, Cloetingh, S., Windhoffer, G., Fodor, L, Pinter, N., Fejes, I., 2007a. Motion of Adria and ongoing inversion of the Pannonian Basin: Seismicity, GPS velocities, and stress transfer. In: Stein, S., Mazzotti, S. (Eds.), Continental Intraplate Earthquakes: Science, Hazard, and Policy Issues, vol. 425. Geological Society of America Special Paper, pp. 243-262. https:// doi.org/10.1130/2007.2425(16).

Bada, G., Horváth, F., Dovényi, P., Szafián, P., Windhoffer, G., Cloetingh, S., 2007b. Present-day stress field and tectonic inversion in the Pannonian basin. Glob. Planet. Chang. 58, 165-180. https://doi.org/10.1016/j.gloplacha.2007.01.007.

Ballato, P., Nowaczyk, N.R., Landgraf, A., Strecker, M.R., Friedrich, A., Tabatabaei, S.H., 2008. Tectonic control on sedimentary facies pattern and sediment accumulation rates in the Miocene foreland basin of the southern Alborz mountains, northern Iran. Tectonics 27, 1-20. https://doi.org/10.1029/2008TC002278.

Ballato, P., Stockli, D.F., Ghassemi, M.R., Landgraf, A., Strecker, M.R., Hassanzadeh, J., Friedrich, A., Tabatabaei, S.H., 2013. Accommodation of transpressional strain in the Arabia-Eurasia collision zone: New constraints from (U-Th)/He thermochronology in the Alborz mountains, North Iran. Tectonics 32, 1-18. https:// doi.org/10.1029/2012TC003159.

Ballato, P., Cifelli, F., Heidarzadeh, G., Ghassemi, M.R., Wickert, A.D., Hassanzadeh, J., Dupont-Nivet, G., Balling, P., Sudo, M., Zeilinger, G., Schmitt, A.K., Mattei, M., Strecker, M.R., 2016. Tectono-sedimentary evolution of the northern Iranian Plateau: insights from middle-late Miocene foreland-basin deposits. Basin Res. 29, 417-446. https://doi.org/10.1111/bre.12180.

Banks, C.J., Robinson, A.G., Williams, M.P., 1997. Structure and regional tectonics of the Achara-Trialeti fold belt and the adjacent Rioni and Kartli foreland basins, Republic of Georgia. In: Robinson, A.G. (Ed.), Regional and Petroleum Geology of the Blacks Sea and Surrounding Region: AAPG Memoirs 68. Tulsa, Oklahoma, pp. 331-346. 
Barber, D.E., Stockli, D.F., Horton, B.K., Koshnaw, R.I., 2018. Cenozoic exhumation and foreland basin evolution of the Zagros orogen during the Arabia-Eurasia collision, Western Iran. Tectonics 37, 4396-4420. https://doi.org/10.1029/2018TC005328.

Barrier, E., Vrielynck, B., 2008. Palaeotectonic Maps of the Middle East. CCMW/CGMW, Paris.

Barrier, E., Vrielynck, B., Brouillet, J.F., Brunet, M.-F., 2018. Paleotectonic reconstruction of the central Tethyan realm. In: Tectonono-sedimentarypalinspastic maps from late Permian to Pliocene. CCGM/CGMW, Pari (Contributors: Angiolini L., Kaveh F., Poisson A., Pourteau A., Plunder A. Robertson A., Shekawat R., Sosson M., Zanchi, A.).

Bazhenov, M.L., Burtman, V.S., 2002. Eocene paleomagnetism of the Caucasus (Southwest Georgia): Oroclinal bending in the Arabian syntaxis. Tectonophysics 344, 247-259. https://doi.org/10.1016/S0040-1951(01)00189-5.

Bergerat, F., Vangelov, D., Dimov, D., 2010. Brittle deformation, palaeostress field reconstruction and tectonic evolution of the Eastern Balkanides (Bulgaria) during Mesozoic and Cenozoic times. In: Sosson, M., Kaymakci, N., Stephenson, R.A., Bergerat, F., Starostenko, V. (Eds.), Sedimentary Basin Tectonics from the Black Sea and Caucasus to the Arabian Platform, vol. 340. Geological Society, London, Special Pubblications, pp. 70-111.

Boccaletti, M., Manetti, P., Peccerillo, A., Stanisheva-Vassileva, G., 1978. Late Cretaceous high-potassium volcanism in eastern Srednogorie, Bulgaria. Bull. Geol. Soc. Am. 89, 439-447. https://doi.org/10.1130/0016-7606(1978)89<439:LCHVIE > 2.0.CO;2.

Brandon, M.T., 1992. Decomposition of fission-track grain-age distributions. Am. J. Sci. 292, 535-564.

Brun, J.P., Nalpas, T., 1996. Graben inversion in nature and experiments. Tectonics 15, 677-687.

Buiter, S.J.H., Pfiffner, O.A., 2003. Numerical models of the inversion of half-graben basins. Tectonics 22, 1057-1073. https://doi.org/10.1029/2002tc001417.

Buiter, S.J.H., Pfiffner, O.A., Beaumont, C., 2009. Inversion of extensional sedimentary basins: a numerical evaluation of the localisation of shortening. Earth Planet. Sci. Lett. 288, 492-504. https://doi.org/10.1016/j.epsl.2009.10.011.

Cavazza, W., Zattin, M., 2015. Exhuming Anatolia: the Italian contribution to the lowtemperature thermochronological study of Turkey and the surrounding regions. Acta Vulcanol. 27, 111-122.

Cavazza, W., Albino, I., Zattin, M., Galoyan, G., Imamverdiyev, N., Melkonyan, R., 2015. Thermochronometric evidence for Miocene tectonic reactivation of the SevanAkera suture zone (Lesser Caucasus): A far-field tectonic effect of the ArabiaEurasia collision? In: Sosson, M., Stephenson, R.A., Adamia, S.A. (Eds.), Tectonic Evolution of the Eastern Black Sea and Caucasus, vol. 428. Geological Society, London, Special Publications, pp. 187-198.

Cavazza, W., Cattò, S., Zattin, M., Okay, A.I., Reiners, P., 2018. Thermochronology of the Miocene Arabia-Eurasia collision zone of southeastern Turkey. Geosphere 14, 2277-2293. https://doi.org/10.1130/GES01637.1.

Cavazza, W., Albino, I., Galoyan, G., Zattin, M., Cattò, S., 2019. Continental accretion and incremental deformation in the thermochronologic evolution of the Lesser Caucasus. Geosci. Front. https://doi.org/10.1016/j.gsf.2019.02.007.

Cloetingh, S., Wortel, R., Vlaar, N.J., 1989. On the Initiation of Subduction zones. Pure Appl. Geophys. 129, 7-25.

Cloetingh, S., Spadini, G., Van Wees, J.D., Beekman, F., 2003. Thermo-mechanical modelling of Black Sea Basin (de)formation. Sediment. Geol. 156, 169-184. https://

doi.org/10.1016/S0037-0738(02)00287-7.

Cloetingh, S., Ziegler, P.A., Beekman, F., Andriessen, P.A.M., Matenco, L., Bada, G., Garcia-Castellanos, D., Hardebol, N., Dezes, P., Sokoutis, D., 2005. Lithospheric memory, state of stress and rheology: Neotectonic controls on Europe's intraplate continental topography. Quat. Sci. Rev. 24, 241-304. https://doi.org/10.1016/j. quascirev.2004.06.015.

Cloetingh, S., Bada, G., Matenco, L., Lankreijer, A., Horváth, F., Dinu, C., 2006. Modes of basin (de)formation, lithospheric strength and vertical motions in the PannonianCarpathian system: Inferences from thermo-mechanical modelling. In: Gee, D.G., Stephenson, R.A. (Eds.), European Lithosphere Dynamics, vol. 32. Geological Society, London, Memoirs, pp. 207-221. https://doi.org/10.1144/GSL. MEM.2006.032.01.12.

Cloetingh, S., Ziegler, P.A., Beekman, F., Burov, E.B., Garcia-Castellanos, D., Matenco, L., 2015. Tectonic models for the evolution of sedimentary basins. In: Schubert, G. (Ed.), Treatise on Geophysics, Second edition. Elsevier B.V, pp. 513-592. https:// doi.org/10.1016/B978-0-444-53802-4.00117-2.

Cowgill, E., Forte, A.M., Niemi, N., Avdeev, B., Tye, A., Trexler, C., Javakhishvili, Z., Elashvili, M., Godoladze, T., 2016. Relict basin closure and crustal shortening budgets during continental collision: an example from Caucasus sediment provenance. Tectonics 35, 2918-2947. https://doi.org/10.1002/2016TC004295.

de Lugt, I.R., van Wees, J.D., Wong, T.E., 2003. The tectonic evolution of the southern Dutch North Sea during the Palaeogene: Basin inversion in distinct pulses. Tectonophysics 373, 141-159. https://doi.org/10.1016/S0040-1951(03)00284-1. DeCelles, P.G., Giles, K.A., 1996. Foreland basin system. Basin Res. 8, 105-124.

Doglioni, C., Carminati, E., Cuffaro, M., Scrocca, D., 2007. Subduction kinematics and dynamic constraints. Earth-Sci. Rev. 83, 125-175. https://doi.org/10.1016/j. earscirev.2007.04.001

Donelick, R.A., Ketcham, R.A., Carlson, W.D., 1999. Variability of apatite fission-track annealing kinetics: II. Crystallographic orientation effects. Am. Mineral. 84, 1224 1234. https://doi.org/10.2138/am-1999-0902.

Donelick, R.A., O'Sullivan, P.B., Ketcham, R.A., 2005. Apatite fission-track analysis. Rev.

Mineral. Geochem. 58, 49-94. https://doi.org/10.2138/rmg.2005.58.3.

Farley, K.A., 2000. Helium diffusion from apatite: General behavior as illustrated by

Durango fluorapatite. J. Geophys. Res. Solid Earth 105, 2903-2914. https:// doi.org/ 10.1029/1999jb900348.
Farley, K.A., 2002. (U-Th)/He dating: techniques, calibrations, and applications. Rev. Mineral. Geochem. 47, 819-844. https://doi.org/10.2138/rmg.2002.47.18.

Farley, K.A., Wolf, R.A., Silver, L.T., 1996. The effects of long alpha-stopping distances on (U-Th)/He ages. Geochim. Cosmochim. Acta 60, 4223-4229. https://doi.org/ 10.1016/S0016-7037(96)00193-7.

Finetti, I., Bricchi, G., Del Ben, A., Pipan, M., Xuan, Z., 1988. Geophysical study of the Black Sea. Boll. Geofis. Teor. Appl. 30, 197-324.

Flowers, R.M., Ketcham, R.A., Shuster, D.L., Farley, K.A., 2009. Apatite (U-Th)/He thermochronometry using a radiation damage accumulation and annealing model. Geochim. Cosmochim. Acta 73, 2347-2365. https://doi.org/10.1016/j. gca.2009.01.015.

Flowers, R.M., Farley, K.A., Ketcham, R.A., 2015. A reporting protocol for thermochronologic modeling illustrated with data from the Grand Canyon. Earth Planet. Sci. Lett. 432, 425-435. https://doi.org/10.1016/j.epsl.2015.09.053. Forte, A.M., Cowgill, E., Murtuzayev, I., Kangarli, T., Stoica, M., 2013. Structural geometries and magnitude of shortening in the eastern Kura fold-thrust belt, Azerbaijan: Implications for the development of the Greater Caucasus Mountains. Tectonics 32, 688-717. https://doi.org/10.1002/tect.20032.

Forte, A.M., Cowgill, E., Whipple, K.X., 2014. Transition from a singly vergent to doubly vergent wedge in a young orogen: the Greater Caucasus. Tectonics 33, 2077-2101.

https://doi.org/10.1002/2014TC003651.

Funiciello, F., Faccenna, C., Heuret, A., Lallemand, S., Di Giuseppe, E., Becker, T.W., 2008. Trench migration, net rotation and slab-mantle coupling. Earth Planet. Sci. Lett. 271, 233-240. https://doi.org/10.1016/j.epsl.2008.04.006.

Gamkrelidze, P., 1949. Geological Structure of the Adjara-Trialetian Folded System. Acad. Sci. Georgia Press, Tbilisi (378 pp).

Gamkrelidze, I., Koiava, K., Mosar, J., Kvaliashvili, L., Mauvilly, J., 2018. Main features of geological structure and a new tectonic map of Georgia. In: EGU General

Assembly, 2018. https://doi.org/10.13140/RG.2.2.26540.56963.

Gamkrelidze, I., Okrostsvaridze, A., Maisadze, F., Basheleishvili, L., Boichenko, G., 2019. Main features of geological structure and geotourism potential of Georgia, the Caucasus. Mod. Environ. Sci. Eng. 5, 422-442. https://doi.org/10.15341/mese (2333-2581)/05.05.2019/010.

Gautheron, C., Tassan-Got, L., Barbarand, J., Pagel, M., 2009. Effect of alpha-damage annealing on apatite (U-Th)/He thermochronology. Chem. Geol. 266, 157-170. https://doi.org/10.1016/j.chemgeo.2009.06.001.

Gavillot, Y., Axen, G.J., Stockli, D.F., Horton, B.K., Fakhari, M.D., 2010. Timing of thrust activity in the High Zagros fold-thrust belt, Iran, from (U-Th)/He thermochronometry. Tectonics 29. https://doi.org/10.1029/2009TC002484.

Georgiev, G., Dabovski, C., Stanisheva-Vassileva, G., 2001. East Srednogorie-Balkan Rift Zone. In: Ziegler, P.A., Cavazza, W., Robertson, A.H.F., Crasquin-Soleau, S. (Eds.), Peri-Thetys Memoir 6: Peri-Tethyan Rift/Wrench Basins and Passive Margins. M émoires du Muséum National d'Histoire Naturelle, Paris, pp. 259-293.

Gleadow, A.J.W., Duddy, I.R., 1981. A natural long-term track annealing experiment for apatite. Nucl. Tracks 5, 169-174.

Gorür, N., 1988. Timing of opening of the Black Sea basin. Tectonophyisics 147, 247-262.

Guest, B., Stockli, D.F., Grove, M., Axen, G.J., Lam, P.S., Hassanzadeh, J., 2006. Thermal histories from the central Alborz Mountains, northern Iran: Implications for the spatial and temporal distribution of deformation in northern Iran. Bull. Geol. Soc. Am. 118, 1507-1521. https://doi.org/10.1130/B25819.1.

Hall, R., Cottam, M.A., Wilson, M.E.J., 2011. The SE Asian gateway: History and tectonics of the Australia-Asia collision. In: Hall, R., Cottam, M.A., Wilson, M.E.J. (Eds.), The SE Asian Gateway: History and Tectonics of the Australia-Asia Collision, vol. 355. Geological Society, London, Special Pubblications, pp. 1-6. https://doi. org/10.1144/SP355.1.

Heuret, A., Lallemand, S., 2005. Plate motions, slab dynamics and back-arc deformation. Phys. Earth Planet. Inter. 149, 31-51. https://doi.org/10.1016/j.pepi.2004.08.022.

Heuret, A., Funiciello, F., Faccenna, C., Lallemand, S., 2007. Plate kinematics, slab shape and back-arc stress: a comparison between laboratory models and current subduction zones. Earth Planet. Sci. Lett. 256, 473-483. https://doi.org/10.1016/j. epsl.2007.02.004.

Hooper, R.J., Goh, L.S., Dewey, F., 1995. The inversion history of the northeastern margin of the Broad Fourteens Basin. In: Buchanan, J.G., Buchanan, P.G. (Eds.), Basin Inversion, vol. 88. Geological Society, London, Special Publications, pp. 307-317. https://doi.org/10.1144/GSL.SP.1995.088.01.17.

Horton, B.K., Fuentes, F., Boll, A., Starck, D., Ramirez, S.G., Stockli, D.F., 2016. Andean stratigraphic record of the transition from backarc extension to orogenic shortening: a case study from the northern Neuquén Basin, Argentina. J. S. Am. Earth Sci. 71, 17-40. https://doi.org/10.1016/j.jsames.2016.06.003.

Horváth, F., Bada, G., Szafián, P., Tari, G., Ádám, A., Cloetingh, S., 2006. Formation and

deformation of the Pannonian Basin: Constraints from observational data. Geol. Soc. Mem. 32, 191-206. https://doi.org/10.1144/GSL.MEM.2006.032.01.11. Hurford,

A.J., Green, P.F., 1983. The zeta age calibration of fission-track dating. Chem. Geol. 41, 285-317.

Jiang, H., Han, J., Chen, H., Zheng, Y., Lu, W., Deng, G., Tan, Z., 2017. Intra-continental back-arc basin inversion and late Carboniferous magmatism in Eastern Tianshan, NW China: Constraints from the Shaquanzi magmatic suite. Geosci. Front. 8, 1447-1467. https://doi.org/10.1016/j.gsf.2017.01.008.

Jolivet, L., Huchon, P., Rangin, C., 1989. Tectonic setting of Western Pacific marginal $\mathrm{X}$. basins. Tectonophysics 160, 23-47. https://doi.org/10.1016/0040-1951(89)90382-

Karakhanyan, A., Vernant, P., Doerflinger, E., Avagyan, A., Philip, H., Aslanyan, R., Champollion, C., Arakelyan, S., Collard, P., Baghdasaryan, H., Peyret, M., Davtyan, V., Calais, E., Masson, F., 2013. GPS constraints on continental deformation 
in the Armenian region and Lesser Caucasus. Tectonophysics 592, 39-45. https:// doi.org/10.1016/j.tecto.2013.02.002

Kato, N., Sato, H., Imaizumi, T., Ikeda, Y., Okada, S., Kagohara, K., Kawanaka, T., Kasahara, K., 2004. Seismic reflection profiling across the source fault of the 2003 Northern Miyagi earthquake (Mj 6.4), NE Japan: Basin inversion of Miocene backarc rift. Earth, Planets Sp. 56, 1369-1374. https://doi.org/10.1186/BF03353362

Kazmin, V.G., Schreider, A.A., Bulychev, A.A., 2000. Early stages of evolution of the Black Sea. In: Bozkurt, E., Winchester, J.A., Piper, J.D.A. (Eds.), Tectonics and Magmatism in Turkey and the Surrounding Area, vol. 173. Geological Society of London, Special Publications, pp. 235-249. https://doi.org/10.1144/GSL. SP.2000.173.01.12.

Ketcham, R.A., 2005. Forward and inverse modeling of low-temperature thermochronometry data. Rev. Mineral. Geochem. 58, 275-314. https://doi.org/ 10.2138/rmg.2005.58.11.

Ketcham, R.A., Donelick, R.A., Carlson, W.D., 1999. Variability of apatite fission-track annealing kinetics: III. Extrapolation to geological time scales. Am. Mineral. 84, 1235-1255. https://doi.org/10.2138/Am.2006.464.

Ketcham, R.A., Carter, A., Donelick, R.A., Barbarand, J., Hurford, A.J., 2007. Improved modeling of fission-track annealing in apatite. Am. Mineral. 92, 799-810. https:// doi.org/10.2138/am.2007.2281.

Ketcham, R.A., Gautheron, C., Tassan-Got, L., 2011. Accounting for long alpha-particle stopping distances in (U-Th-Sm)/He geochronology: Refinement of the baseline case. Geochim. Cosmochim. Acta 75, 7779-7791. https://doi.org/10.1016/j. gca.2011.10.011.

Koçyiğit, A., Yllmaz, A., Adamia, S.A., Kuloshvili, S., 2001. Neotectonics of East Anatolian Plateau (Turkey) and Lesser Caucasus: Implication for transition from thrusting to strike-slip faulting. Geodin. Acta 14, 177-195. https://doi.org/10.1080/ 09853111.2001.11432443.

Letouzey, J., Biju-Duval, B., Dorkel, A., Gonnard, R., Kristchev, K., Montadert, L., Sungurlu, O., 1977. The Black Sea: A marginal basin. Geophysical and geological data. In: Biju-Duval, B., Montadert, L. (Eds.), Structural History of the Mediterranean Basins. Split - Yougoslavie, pp. 363-376.

Letouzey, J., Werner, P., Marty, A., 1990. Fault reactivation and structural inversion. Backarc and intraplate compressive deformations. Example of the eastern Sunda shelf (Indonesia). In: Angelier, J. (Ed.), Geodynamic Evolution of the Eastern Eurasian Margin, pp. 341-362.

Lisker, F., Ventura, B., Glasmacher, U.A., 2009. Apatite thermochronology in modern geology. In: Lisker, F., Ventura, B., Glasmacher, U.A. (Eds.), Thermochronological Methods, vol. 324. Geological Society of London, Special Publications, pp. 1-23. https://doi.org/10.1144/SP324.1.

Lordkipanidze, M.B., Zakariadze, G.S., Popolitov, E.I., 1979. Volcanic evolution of the marginal and interarc basins. Tectonophyises 57, 71-83.

Lozar, F., Polino, R., 1997. Early Cenozoic uprising of the Great Caucasus revealed by reworked calcareous nannofossils. In: EUG. Strasbourg, France, p. 141. Madanipour,

S., Ehlers, T.A., Yassaghi, A., Enkelmann, E., 2017. Accelerated middle Miocene exhumation of the Talesh Mountains constrained by U-Th/He thermochronometry: evidence for the Arabia-Eurasia collision in the NW Iranian Plateau. Tectonics 36, 1538-1561. https://doi.org/10.1002/2016TC004291.

Malusà, M.G., Garzanti, E., 2019. The sedimentology of detrital thermochronology. In: Malusà, M.G., Fitzgerald, P.G. (Eds.), Fission-Track Thermochronology and its Application to Geology. Springer, Cham, pp. 123-143. https://doi.org/10.1007/ 978-3-319-89421-8_7.

Mayringer, F., Treloar, P.J., Gerdes, A., Finger, F., Shengelia, D., 2011. New age data from the Dzirula Massif, Georgia: Implications for the evolution of the Caucasian Variscides. Am. J. Sci. 311, 404-441. https://doi.org/10.2475/05.2011.02.

Miall, A.D., 2013. Principles of Sedimentary Basin Analysis. Springer Science \& Business Media. https://doi.org/10.1016/s0037-0738(02)00096-9.

Mosar, J., Kangarli, T., Bochud, M., Glasmacher, U.A., Rast, A., Brunet, M.-F., Sosson, M. 2010. Cenozoic-recent tectonics and uplift in the Greater Caucasus: A perspective from Azerbaijan. In: Sosson, M., Kaymakci, N., Stephenson, R.A., Bergerat, F., Starostenko, V. (Eds.), Sedimentary Basin Tectonics from the Black Sea and Caucasus to the Arabian Platform, vol. 340. Geological Society, London, Special Publications, pp. 261-280. https://doi.org/10.1144/SP340.12.

Motavalli-Anbaran, S.H., Zeyen, H., Jamasb, A., 2016. 3D crustal and lithospheric mode of the Arabia-Eurasia collision zone. J. Asian Earth Sci. 122, 158-167. https://doi. org/10.1016/j.jseaes.2016.03.012.

Mumladze, T., Forte, A.M., Cowgill, E.S., Trexler, C.C., Niemi, N.A., Burak Yıkalmaz, M. Kellogg, L.H., 2015. Subducted, detached, and torn slabs beneath the Greater Caucasus. GeoResJ 5, 36-46. https://doi.org/10.1016/j.grj.2014.09.004.

Munteanu, I., Matenco, L., Dinu, C., Cloetingh, S., 2011. Kinematics of back-arc inversion of the Western Black Sea Basin. Tectonics 30, 1-21. https://doi.org/10.1029/ 2011TC002865.

Munteanu, I., Willingshofer, E., Sokoutis, D., Matenco, L., Dinu, C., Cloetingh, S., 2013. Transfer of deformation in back-arc basins with a laterally variable rheology: Constraints from analogue modelling of the Balkanides-Western Black Sea inversion. Tectonophysics 602, 223-236. https://doi.org/10.1016/j.tecto.2013.03.009.

Nalpas, T., Le Douaran, S., Brun, J.P., Unternehr, P., Richert, J.P., 1995. Inversion of the Broad Fourteens Basin (offshore Netherlands), a small-scale model investigation. Sediment. Geol. 95, 237-250. https://doi.org/10.1016/0037-0738(94)00113-9. Nemčok, M., Glonti, B., Yukler, A., Marton, B., 2013. Development history of the foreland plate trapped between two converging orogens; Kura Valley, Georgia, case study. In: Nemčok, M., Mora, A., Cosgrove, J.W. (Eds.), Thick-Skin-Dominated Orogens: From Initial Inversion to Full Accretion, vol. 377. Geological Society, London, Special Publications, pp. 159-188. https://doi.org/10.1144/SP377.9.
Nikishin, A.M., Korotaev, M.V., Ershov, A.V., Brunet, M.F., 2003. The Black Sea basin: Tectonic history and Neogene-Quaternary rapid subsidence modelling. Sediment. Geol. 156, 149-168. https://doi.org/10.1016/S0037-0738(02)00286-5. Nikishin, A.M., Ziegler, P.A., Bolotov, S.N., Fokin, P.A., 2011. Late Palaeozoic to Cenozoic evolution of the Black Sea-Southern Eeastern Europe region: a view from the Russian Platform. Turkish. J. Earth Sci. 21, 571-634. https://doi.org/10.3906/ yer-1005-22.

Nikishin, A.M., Okay, A.I., Tüysüz, O., Demirer, A., Wannier, M., Amelin, N., Petrov, E., 2015a. The Black Sea basins structure and history: New model based on new deep penetration regional seismic data. Part 1: Basins structure and fill. Mar. Pet. Geol. 59, 638-655. https://doi.org/10.1016/j.marpetgeo.2014.08.018.

Nikishin, A.M., Okay, A.I., Tüysüz, O., Demirer, A., Wannier, M., Amelin, N., Petrov, E., 2015b. The Black Sea basins structure and history: New model based on new deep penetration regional seismic data. Part 2: Tectonic history and paleogeography. Mar. Pet. Geol. 59, 656-670. https://doi.org/10.1016/j.marpetgeo.2014.08.018.

Nikishin, A.M., Wannier, M., Alekseev, A.S., Almendinger, O.A., Fokin, P.A., Gabdullin, R.R., Khudoley, A.K., Kopaevich, L.F., Mityukov, A.V., Petrov, E.I., Rubtsova, E.V., 2017. Mesozoic to recent geological history of southern Crimea and the Eastern Black Sea region. In: Sosson, M., Stephenson, R.A., Adamia, S.A. (Eds.), Tectonic Evolution of the Eastern Black Sea and Caucasus, vol. 428. Geological Society, London, Special Publications, pp. 241-264. https://doi.org/10.1144/ SP428.1.

Nikishin, A.M., Ziegler, P.A., Panov, D.I., Nazarevich, B.P., Brunet, M.F., Stephenson, R. A., Bolotov, S.N., Korotaev, M.V., Tikhomirov, P.L., 2001. Mesozoic and Cenozoic evolution of the Scythian Platform-Black Sea-Caucasus domain. In: Ziegler, P.A., Cavazza, W., Robertson, A.H.F., Crasquin-Soleau, S. (Eds.), Peri-Tethys Memoir 6: Peri-Tethyan Rift/Wrench Basins and Passive Margins. National Museum of Natural History, Paris, pp. 295-346.

Okamura, Y., Watanabe, M., Morijiri, R., Satoh, M., 1995. Rifting and basin inversion in the eastern margin of the Japan Sea. Island Arc 4, 166-181. https://doi.org/

10.1111/j.1440-1738.1995.tb00141.x.

Okay, A.I., Tüysüz, O., 1999. Tethyan sutures of northern Turkey. In: Durand, B., Jolivet, L., Horváth, F., Séranne, M. (Eds.), The Mediterranean Basins: Tertiary Extension within the Alpine Orogen, 156. Geological Society of London, Special Publications, pp. 475-515. doi:10.1144/gsl.sp.1999.156.01.22.

Okay, A.I., Şengor, A.M.C., Gorür, N., 1994. Kinematic history of the opening of the Black Sea and its effect on the surrounding regions. Geology 22, 267-270. https://doi.org/ 10.1130/0091-7613(1994)022<0267:KHOTOO > 2.3.CO;2.

Okay, A.I., Zattin, M., Cavazza, W., 2010. Apatite fission-track data for the Miocene Arabia-Eurasia collision. Geology 38, 35-38. https://doi.org/10.1130/G30234.1. Okrostsvaridze, A., Chung, S.L., Chang, Y.H., Gagnidze, N., Bluashvili, D., 2018a. Analysis of magmatic processes of the Paleogene Adjara-Trialeti foldrift zone, Lesser Caucasus: Implication from zircon U-Pb geochronology. In: Neubauer, F., Brendel, U., Friedl, G. (Eds.), Geologica Balcanica (XXI International Congress of the CBGA). Bulgarian Academy of Sciences, p. 298. https://doi.org/10.1017/ CBO9781107415324.004.

Okrostsvaridze, A., Chung, S.L., Chang, Y.H., Gagnidze, N., Boichenko, G., Gogoladze, S., 2018b. Zircons U-Pb geochronology of the ore-bearing plutons of Adjara-Trialeti folded zone, Lesser Caucasus and analysis of the magmatic processes. Bull. Georg. Natl. Acad. Sci. 12, 90-99.

Peyton, S.L., Carrapa, B., 2013. An introduction to low-temperature thermochronologic techniques, methodology, and applications. In: Knight, C., Cuzella, J. (Eds.), Application of Structural Methods to Rocky Mountain Hydrocarbon Exploration and Development: AAPG Studies in Geology, 65, pp. 15-36. https://doi.org/10.1306/ 13381688 St653578.

Pupp, M., Bechtel, A., Ćorić, S., Gratzer, R., Rustamov, J., Sachsenhofer, R.F., 2018. Eocene and Oligo-Miocene source rocks in the Rioni and Kura Basins of Georgia: depositional environment and petroleum potential. J. Pet. Geol. 41, 367-392. https://doi.org/10.1111/jpg.12708.

Reilinger, R., McClusky, S., Vernant, P., Lawrence, S., Ergintav, S., Cakmak, R., Ozener, H., Kadirov, F., Guliev, I., Stepanyan, R., Nadariya, M., Hahubia, G., Mahmoud, S., Sakr, K., ArRajehi, A., Paradissis, D., Al-Aydrus, A., Prilepin, M., Guseva, T., Evren, E., Dmitrotsa, A., Filikov, S.V., Gomez, F., Al-Ghazzi, R., Karam, G., 2006. GPS constraints on continental deformation in the Africa-ArabiaEurasia continental collision zone and implications for the dynamics of plate interactions. J. Geophys. Res. Solid Earth 111, 1-26. https://doi.org/10.1029/ 2005JB004051.

Reiners, P.W., 2005. Zircon (U-Th)/He thermochronometry. Rev. Mineral. Geochem. 58, 151-179. https://doi.org/10.2138/rmg.2005.58.6.

Reiners, P.W., Spell, T.L., Nicolescu, S., Zanetti, K.A., 2004. Zircon (U-Th)/He thermochronometry: He diffusion and comparisons with ${ }^{40} \mathrm{Ar} /{ }^{39} \mathrm{Ar}$ dating. Geochim. Cosmochim. Acta 68, 1857-1887. https://doi.org/10.1016/j.gca.2003.10.021.

Robinson, A.G., Banks, C.J., Rutherford, M.M., Hirst, J.P.P., 1995a. Stratigraphic and structural development of the Eastern Pontides, Turkey. J. Geol. Soc. Lond. 152, 861-872. https://doi.org/10.1144/gsjgs.152.5.0861.

Robinson, A.G., Spadini, G., Cloetingh, S., Rudat, J., 1995b. Stratigraphic evolution of the Black Sea: inferences from basin modelling. Mar. Pet. Geol. 12, 821-835. https:// doi.org/10.1016/0264-8172(95)98850-5.

Robinson, A.G., Rudat, J.H., Banks, C.J., Wiles, R.L.F., 1996. Petroleum geology of the Black Sea. Mar. Pet. Geol. 13, 195-223. https://doi.org/10.1016/0264-8172(95) 00042-9.

Robinson, A.G., Griffith, E.T., Gardiner, A.R., Home, A.K., 1997. Petroleum geology of the georgian fold and thrust belts and foreland basins. In: Robinson, A.G. (Ed.), Regional and Petroleum Geology of the Black Sea and Surrounding Region: AAPG Memoirs, 68, pp. 347-367. 
Rolland, Y., 2017. Caucasus collisional history: Review of data from East Anatolia to West Iran. Gondwana Res. 49, 130-146. https://doi.org/10.1016/j.gr.2017.05.005.

Rolland, Y., Hassig, M., Bosch, D., Meijers, M.J.M., Sosson, M., Bruguier, O., Adamia, S. A., Sadradze, N., 2016. A review of the plate convergence history of the East Anatolia-Transcaucasus region during the Variscan: Insights from the Georgian basement and its connection to the Eastern Pontides. J. Geodyn. 96, 131-145. https://doi.org/10.1016/j.jog.2016.03.003.

Roure, F., 2008. Foreland and hinterland basins: what controls their evolution? Swiss J. Geosci. 101, 1-4. https://doi.org/10.1007/s00015-008-1285-x.

Sachsenhofer, R.F., Popov, S.V., Coric, S., Mayer, J., Misch, D., Morton, M.T., Pupp, M., Rauball, J., Tari, G., 2018. Paratethyan petroleum source rocks: an overview. J. Pet. Geol. 41, 219-245. https://doi.org/10.1111/jpg.12702.

Shatilova, L.I., Maissuradze, L.S., Koiava, K.P., Kokolashvili, I.M., Bukhsianidze, M.G., Bruch, A.A., 2020. The Environmental History of Georgia during the Late Miocene Based of Foraminifera and Pollen. Universal, Tbilisi.

Shillington, D.J., White, N., Minshull, T.A., Edwards, G.R.H., Jones, S.M., Edwards, R.A. Scott, C.L., 2008. Cenozoic evolution of the eastern Black Sea: a test of depthdependent stretching models. Earth Planet. Sci. Lett. 265, 360-378. https://doi.org/ 10.1016/j.epsl.2007.10.033.

Shuster, D.L., Farley, K.A., 2009. The influence of artificial radiation damage and thermal annealing on helium diffusion kinetics in apatite. Geochim. Cosmochim.

Acta 73, 183-196. https://doi.org/10.1016/j.gca.2008.10.013.

Shuster, D.L., Flowers, R.M., Farley, K.A., 2006. The influence of natural radiation damage on helium diffusion kinetics in apatite. Earth Planet. Sci. Lett. 249, 148-161. https://doi.org/10.1016/j.epsl.2006.07.028.

Sokhadze, G., Floyd, M., Godoladze, T., King, R., Cowgill, E.S., Javakhishvili, Z., Hahubia, G., Reilinger, R., 2018. Active convergence between the Lesser and Greater Caucasus in Georgia: Constraints on the tectonic evolution of the Lesser-Greater Caucasus continental collision. Earth Planet. Sci. Lett. 481, 154-161. https://doi. org/10.1016/j.epsl.2017.10.007.

Sosson, M., Rolland, Y., Müller, C., Danelian, T., Melkonyan, R., Kekelia, S., Adamia, S. A., Babazadeh, V., Kangarli, T., Avagyan, A., Galoyan, G., Mosar, J., 2010. Subductions, obduction and collision in the Lesser Caucasus (Armenia, Azerbaijan, Georgia), new insights. In: Sosson, Marc, Kaymakci, N., Stephenson, R.A., Bergerat, F., Starostenko, V. (Eds.), Sedimentary Basin Tectonics from the Black Sea and Caucasus to the Arabian Platform, vol. 340. Geological Society of London, Special Publications, pp. 329-352. https://doi.org/10.1144/SP340.14.

Sosson, M., Stephenson, R., Sheremet, Y., Rolland, Y., Adamia, S.A., Melkonian, R. Kangarli, T., Yegorova, T., Avagyan, A., Galoyan, G., Danelian, T., Hassig, M. Meijers, M., Müller, C., Sahakyan, L., Sadradze, N., Alania, V., Enukidze, O. Mosar, J., 2016. The eastern Black Sea-Caucasus region during the Cretaceous: New evidence to constrain its tectonic evolution. Compt. Rendus Geosci. 348, 23-32. https://doi.org/10.1016/j.crte.2015.11.002

Spadini, G., Robinson, A., Cloetingh, S., 1996. Western versus Eastern Black Sea tectonic evolution: Pre-rift lithospheric controls on basin formation. Tectonophysics 266, 139-154. https://doi.org/10.1016/S0040-1951(96)00187-4.

Stampfli, G.M., Hochard, C., 2009. Plate tectonics of the Alpine realm. In: Murphy, J.B., Keppie, J.D., Hynes, A.J. (Eds.), Ancient Orogens and Modern Analogues, 327 Geological Society, London, Special Publications, pp. 89-111. https://doi.org/ 10.1144/SP327.6.

Stephenson, R., Schellart, W.P., 2010. The Black Sea back-arc basin: Insights to its origin from geodynamic models of modern analogues. In: Sosson, M., Kaymakci, N., Stephenson, R.A., Bergerat, F., Starostenko, V. (Eds.), Sedimentary Basin Tectonics from the Black Sea and Caucasus to the Arabian Platform, vol. 340. Geological Society, London, Special Publications, pp. 11-21. https://doi.org/10.1144/SP340.2

Tari, G.C., Simmons, M.D., 2018. History of deepwater exploration in the Black Sea and an overview of deepwater petroleum play types. In: Simmons, M.D., Tari, G.C. Okay, A.I. (Eds.), Petroleum Geology of the Black Sea, vol. 464. Geological Society, London, Special Pubblications, pp. 439-475. https://doi.org/10.1144/SP464.16.

Tari, G., Vakhania, D., Tatishvili, G., Mikeladze, V., Gogritchiani, K., Vacharadze, S., Mayer, J., Sheya, C., Siedl, W., Banon, J.J.M., Sanchez, J.T., 2018. Stratigraphy, structure and petroleum exploration play types of the Rioni Basin, Georgia. In: Simmons, M.D., Tari, G.C., Okay, A.I. (Eds.), Petroleum Geology of the Black Sea, vol. 464. Geological Society, London, Special Publications, pp. 403-438.

Tedliashvili, K.T., 2013. New data on stages in the formation of the pre-alpine continental crust beneath the Khrami Crystalline Massif (Caucasus). Dokl. Earth Sci. 453, 1188-1192. https://doi.org/10.1134/S1028334X13120179.

Tibaldi, A., Alania, V., Bonali, F.L., Enukidze, O., Tsereteli, N., Kvavadze, N., Varazanashvili, O., 2017. Active inversion tectonics, simple shear folding and backthrusting at Rioni Basin, Georgia. J. Struct. Geol. 96, 35-53. https://doi.org/ 10.1016/j.jsg.2017.01.005.

Tsereteli, N., Tibaldi, A., Alania, V., Gventsadse, A., Enukidze, O., Varazanashvili, O. Müller, B.I.R., 2016. Active tectonics of Central-Western Caucasus, Georgia. Tectonophysics 691, 328-344. https://doi.org/10.1016/j.tecto.2016.10.025.

USSR Geological Survey, 1956a. Geological Map of the USSR, 1: 200000 scale, Sheet K38-XV.

USSR Geological Survey, 1956b. Geological Map of the USSR, 1: 200000 scale, Sheet K38-XIV.
USSR Geological Survey, 1956c. Geological Map of the USSR, 1: 200000 scale, Sheet K-

38-XXII.

USSR Geological Survey, 1957a. Geological Map of the USSR, 1: 200000 scale, Sheet K38-XX.

USSR Geological Survey, 1957b. Geological Map of the USSR, 1: 200000 scale, Sheet K38-XXI.

Uyeda, S., McCabe, R., 1983. A possible mechanism of episodic spreading of the Philippine Sea. In: Hashimoto, M., Uyeda, S. (Eds.), Accretion Tectonics in the Circum-Pacific Regions. Tokyo, TerraPub, pp. 291-306.

Van Wijhe, D.H., 1987. Structural evolution of inverted basins in the Dutch offshore. In: Ziegler, P.A. (Ed.), Compressional Intra-Plate Deformations in the Alpine Foreland. Tectonophysics, pp. 171-219. https://doi.org/10.1016/0040-1951(87)90320-9.

Vasey, D.A., Cowgill, E., Roeske, S.M., Niemi, N.A., Godoladze, T., Skhirtladze, I., Gogoladze, S., 2020. Evolution of the Greater Caucasus basement and formation of the Main Caucasus Thrust, Georgia. Tectonics 39. https://doi.org/10.1029/ 2019 TC005828.

Vincent, S.J., Morton, A.C., Carter, A., Gibbs, S., Barabadze, T.G., 2007. Oligocene uplift of the Western Greater Caucasus: an effect of initial Arabia-Eurasia collision. Terra Nova 19, 160. https://doi.org/10.1111/j.1365-3121.2007.00731.x.

Vincent, S.J., Carter, A., Lavrishchev, V.A., Rice, S.P., Barabadze, T.G., Hovius, N., 2011. The exhumation of the western Greater Caucasus: a thermochronometric study. Geol. Mag. 148, 1-21. https://doi.org/10.1017/S0016756810000257.

Vincent, S.J., Hyden, F., Braham, W., 2013a. Along-strike variations in the composition of sandstones derived from the uplifting western Greater Caucasus: Causes and implications for reservoir quality prediction in the Eastern Black Sea. In: Scott, R.A., Smyth, H.R., Morton, A.C., Richardson, N. (Eds.), Sediment Provenance Studies in Hydrocarbon Exploration and Production, vol. 386. Geological Society, London, Special Publications, pp. 111-127. https://doi.org/10.1144/SP386.15.

Vincent, S.J., Morton, A.C., Hyden, F., Fanning, M., 2013b. Insights from petrography, mineralogy and $\mathrm{U}-\mathrm{Pb}$ zircon geochronology into the provenance and reservoir potential of Cenozoic siliciclastic depositional systems supplying the northern margin of the Eastern Black Sea. Mar. Pet. Geol. 45, 331-348. https://doi.org/ 10.1016/j.marpetgeo.2013.04.002.

Vincent, S.J., Braham, W., Lavrishchev, V.A., Maynard, J.R., Harland, M., 2016. The formation and inversion of the western Greater Caucasus Basin and the uplift of the western Greater Caucasus: Implications for the wider Black Sea region. Tectonics 35, 2948-2962. https://doi.org/10.1002/2016TC004204.

Vincent, S.J., Somin, M.L., Carter, A., Vezzoli, G., Fox, M., Vautravers, B., 2020. Testing models of Cenozoic exhumation in the Western Greater Caucasus. Tectonics 1-27. https://doi.org/10.1029/2018tc005451.

Wolf, R.A., Farley, K.A., Silver, L.T., 1996. Helium diffusion and low-temperature thermochronometry of apatite. Geochim. Cosmochim. Acta 60, 4231-4240. https:// doi.org/10.1016/S0016-7037(96)00192-5.

Wolf, R.A., Farley, K.A., Kass, D.M., 1998. Modeling of the temperature sensitivity of the apatite (U-Th)/He thermochronometer. Chem. Geol. 148, 105-114. https://doi.org/ 10.1016/S0009-2541(98)00024-2.

Y.lmaz, A., Adamia, S.A., Chabukiani, A., Chkhotua, T., Erdoğan, K., Tuzcu, S., Karabiyikoğlu, M., 2000. Structural correlation of the southern Transcaucasus (Georgia)-eastern Pontides (Turkey). In: Bozkurt, E., Winchester, J.A., Piper, J.D.A. (Eds.), Tectonics and Magmatism in Turkey and the Surrounding Area, vol. 173. Geological Society of London, Special Publications, pp. 171-182.

Yllmaz, A., Adamia, S.A., Yllmaz, H., 2014. Comparisons of the suture zones along a geotraverse from the Scythian Platform to the Arabian Platform. Geosci. Front. 5, 855-875. https://doi.org/10.1016/j.gsf.2013.10.004.

Ziegler, P.A., 1990. Collision related intra-plate compression deformations in Western and Central Europe. J. Geodyn. 11, 357-388. https://doi.org/10.1016/0264-3707 (90)90017-0.

Ziegler, P.A., 1993. Plate-moving mechanisms: their relative importance. J. Geol. Soc. Lond. 150, 927-940.

Ziegler, P.A., Cloetingh, S., 2004. Dynamic processes controlling evolution of rifted basins. Earth-Sci. Rev. 64, 1-50. https://doi.org/10.1016/S0012-8252(03)00041-2.

Ziegler, P.A., Cloetingh, S., van Wees, J.D., 1995. Dynamics of intra-plate compressional deformation: the Alpine foreland and other examples. Tectonophysics 252, 7-59. https://doi.org/10.1016/0040-1951(95)00102-6.

Ziegler, P.A., Van Wees, J.D., Cloetingh, S., 1998. Mechanical controls on collisionrelated compressional intraplate deformation. Tectonophysics 300, 103-129. https://doi.org/10.1016/S0040-1951(98)00236-4.

Ziegler, P.A., Bertotti, G., Cloetingh, S., 2002. Dynamic processes controlling foreland development - the role of mechanical (de)coupling of orogenic wedges and forelands. Stephan Mueller Spec. Publ. Ser. 1, 17-56. https://doi.org/10.5194/ smsps-1-17-2002

Zoback, M. Lou, 1992. First- and second-order patterns of stress in the lithosphere: the World stress Map Project. J. Geophys. Res. 97, 11703 https://doi.org/10.1029/ 92jb00132.

Zonenshain, L.P., Le Pichon, X., 1986. Deep basins of the Black Sea and Caspian Sea as remnants of Mesozoic back-arc basins. Tectonophysics 13, 181-121. 